\title{
Novel pre-treatments to control bromate formation during ozonation
}

\author{
Antoniou, Maria; Sichel, Cosima; Andre, Klaus; Andersen, Henrik Rasmus
}

Published in:

Journal of Hazardous Materials

Link to article, DOI:

10.1016/j.jhazmat.2016.03.041

Publication date:

2017

Document Version

Peer reviewed version

Link back to DTU Orbit

Citation (APA):

Antoniou, M., Sichel, C., Andre, K., \& Andersen, H. R. (2017). Novel pre-treatments to control bromate formation during ozonation. Journal of Hazardous Materials, 323(Part A), 452-459.

https://doi.org/10.1016/j.jhazmat.2016.03.041

\section{General rights}

Copyright and moral rights for the publications made accessible in the public portal are retained by the authors and/or other copyright owners and it is a condition of accessing publications that users recognise and abide by the legal requirements associated with these rights.

- Users may download and print one copy of any publication from the public portal for the purpose of private study or research.

- You may not further distribute the material or use it for any profit-making activity or commercial gain

- You may freely distribute the URL identifying the publication in the public portal

If you believe that this document breaches copyright please contact us providing details, and we will remove access to the work immediately and investigate your claim 


\section{Novel pre-treatments to control}

\section{bromate formation during ozonation}

Maria G. Antoniou ${ }^{1,2 *}$, Cosima Sichel ${ }^{3,4}$, Klaus Andre ${ }^{3}$ and Henrik R. Andersen ${ }^{1}$.

\section{Highlights}

- Pre-treatments were investigated which inhibit bromate formation in ozonation.

- $\mathrm{ClO}_{2}$ and $\mathrm{MnO}_{4}{ }^{-}$with $\mathrm{NH}_{4}{ }^{+}$were promising pre-treatments for bromate inhibition.

- Atrazine removal was only unaffected by the $\mathrm{MnO}_{4}{ }^{-}$with $\mathrm{NH}_{4}{ }^{+}$pretreatment.

- $\mathrm{MnO}_{4}{ }^{-}$with $\mathrm{NH}_{4}{ }^{+}$pre-treatments appears technical and economically feasible

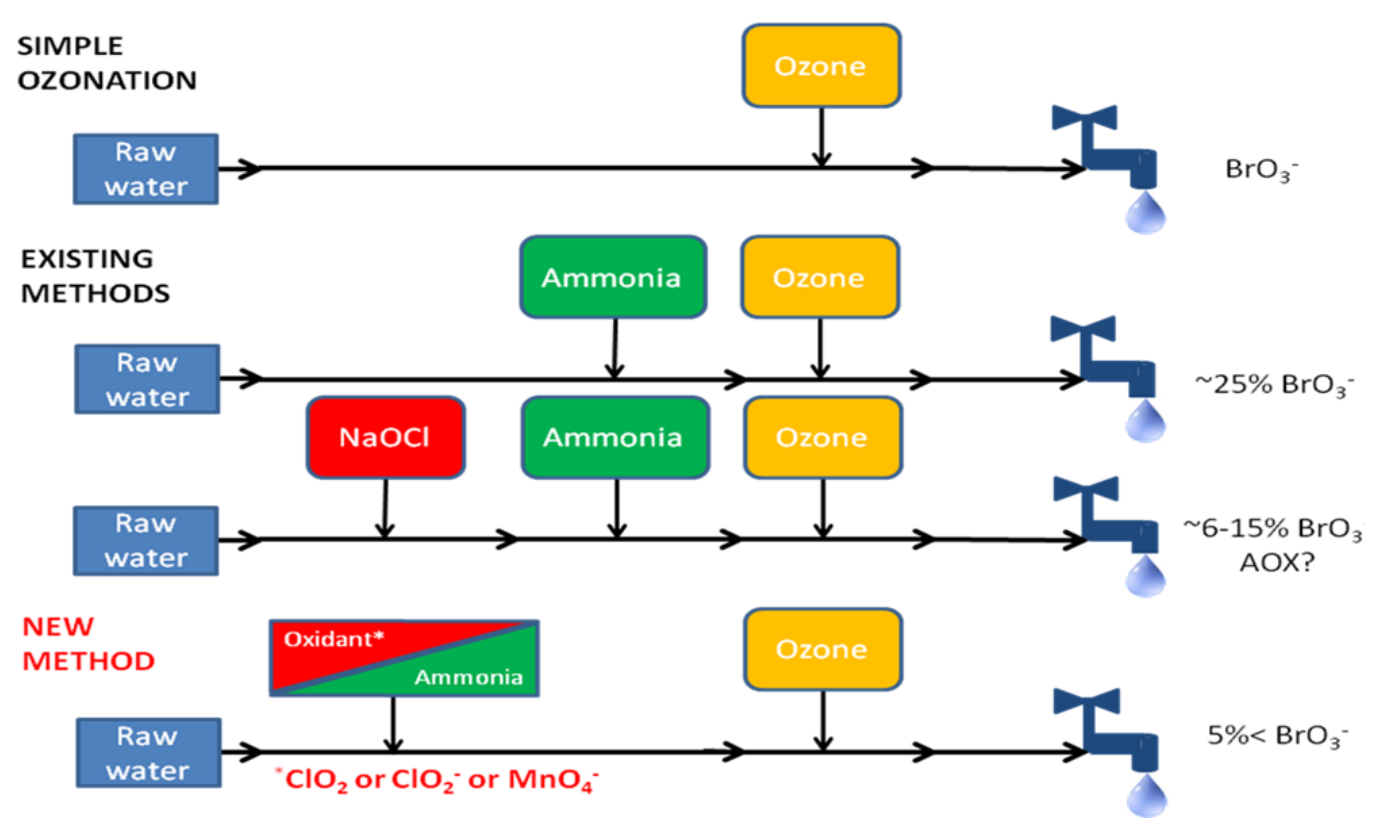

\footnotetext{
${ }^{1}$ Technical University of Denmark (DTU), Department of Environmental Engineering, Miljoevej, Building 113 , 2800 Kgs. Lyngby. ${ }^{2}$ Cyprus University of Technology Department of Environmental Science and Technology, Corner of Athinon and Anexartisias 57, PO Box: 50329, 3603 Lemesos, Cyprus. "Corresponding authors e-mail: maria.antoniou@cut.ac.cy.

${ }^{3}$ Siemens AG, Industry Sector, Industry Automation Division, Water Technologies, Auf der Weide 10, 89312 Günzburg, Germany. ${ }^{4}$ Siemens AG, Industry Sector, Industry Automation Division, Sensors and Communication, I IA SC S PI IBD-E, Oestliche Rheinbrueckenstr. 50, 76187 Karlsruhe, Germany
} 


\begin{abstract}
Worldwide water shortage increase and water quality depletion from microbial and chemical compounds, pose significant challenges for today's water treatment industry. Both the development of new advanced oxidation technologies, but also the enhancement of existing conventional technologies is of high interest. This study tested improvements to conventional ozonation that reduce the formation of the oxidation-by-product bromate, while maintaining the effectiveness for removal emerging contaminants (atrazine). $\mathrm{MnO}_{4}^{-}, \mathrm{ClO}_{2}^{-}, \mathrm{ClO}_{2}, \mathrm{ClO}^{-}$, $\mathrm{CH}_{3} \mathrm{COOO}^{-}, \mathrm{HSO}_{5}^{-}$or $\mathrm{S}_{2} \mathrm{O}_{8}^{-2}$ with $\mathrm{NH}_{4}{ }^{+}$were tested as pre-treatments to ozonation of ground water. Each oxidant and $\mathrm{NH}_{4}{ }^{+}$were added in a single stage or separately prior to ozonation. To the best of our knowledge, this is the first study that has tested all the above-mentioned oxidants for the same water matrix. Based on our results, the most promising pre-treatments were $\mathrm{MnO}_{4}{ }^{-}-\mathrm{NH}_{4}{ }^{+}, \mathrm{ClO}_{2}{ }^{-}-\mathrm{NH}_{4}{ }^{+}$and $\mathrm{ClO}_{2}-\mathrm{NH}_{4}{ }^{+}$. $\mathrm{MnO}_{4}{ }^{-}-\mathrm{NH}_{4}{ }^{+}$was the only pretreatment that didn't inhibit atrazine removal. When compared with the previously proposed $\mathrm{Cl}_{2} / \mathrm{NH}_{4}{ }^{+}$pretreatment, $\mathrm{MnO}_{4}{ }^{-}+\mathrm{NH}_{4}{ }^{+}$was found as effective for preventing $\mathrm{BrO}_{3}{ }^{-}$formation, while atrazine removal was higher. In addition, $\mathrm{MnO}_{4}{ }^{-}+\mathrm{NH}_{4}{ }^{+}$can be added in a single stage (compared to the 2 stage addition of $\mathrm{Cl}_{2} / \mathrm{NH}_{4}{ }^{+}$) without causing the formation of potentially harmful chlorination-by-products.
\end{abstract}

Keywords: ammonia, atrazine, bromate, chlorine dioxide, ozone, permanganate

\title{
1. Introduction
}

The presence and subsequently the removal of emerging contaminants (ECs) like pesticides, hormones, medical drugs and naturally occurring toxic metabolites from water resources poses a challenge for the water industry [1-5]. In order to remove micropollutants in trace concentrations from water resources chemical oxidation technologies such as ozonation and advanced oxidation processes (AOPs) are increasingly applied in different types of source water [2, 6-12]. Ozone $\left(\mathrm{O}_{3}\right)$ is able to remove most ECs with less energy consumption than conventional $\mathrm{UV} / \mathrm{H}_{2} \mathrm{O}_{2}$ AOPs [12-14], but at higher capital costs and with a larger footprint of the treatment unit. The recently developed $\mathrm{UV} / \mathrm{Cl}_{2} \mathrm{AOP}$ appears to be a promising candidate for significantly reducing capital and operational costs for the oxidative removal of trace compounds especially from wastewater treatment plant effluents $[15,16]$.

Nevertheless, ozonation remains a preferred method for the removal of organic ECs as it is a simple to control and implement at existing waterworks. In addition to water purification, $\mathrm{O}_{3}$ has been used for disinfection, taste, color, and odor removal, and the pre-oxidation of drinking water to reduce formation of byproducts in post treatment chlorination [17-19]. Ozone installations are currently found in many water treatment plants primarily for pathogen control and/or for taste and odor control such as the Metropolitan Water District of Southern California and Alameda County Water District in California [19]. This is because, $\mathrm{O}_{3}$ readily reacts with unsaturated bonds in organic molecules through cyclo addition reactions leading to the formation of unstable ozonides that eventually breakdown to aldehydes and ketones. Its ability to form hydroxyl radicals ( $\mathrm{HO}^{\bullet}$ ) as a decomposition intermediate increases the oxidation efficiency of the technology by adding the possibility for non-selective oxidation [20]. A side effect of ozonation is the formation of bromate $\left(\mathrm{BrO}_{3}{ }^{-}\right)$when the source water contains naturally occurring bromide ( $\left.\mathrm{Br}^{-}\right)[17,21-23]$. Bromate is a probable human carcinogen $[22,24]$ and therefore its concentration is regulated in drinking water. $\mathrm{BrO}_{3}{ }^{-}$comprises the only ozonation by-product that is currently being regulated in drinking waters $[18,25,26]$. In the past, the drinking water standard limits for bromate have been decreased to $10.0 \mu \mathrm{g} / \mathrm{L}$ in Europe and in the USA $(0.010 \mathrm{mg} / \mathrm{L})[25,26]$ and even stronger restrictions $(5 \mu \mathrm{g} / \mathrm{L}$ ) have been considered for its annual average concentration [26-28]. Following extensive evaluation of the risks and benefits of ozonation the USEPA decided against the reduction of the $\mathrm{BrO}_{3}{ }_{3}$ limit because technical analyses indicated that many facilities utilizing ozonation for improved disinfection would be unable to meet the stringent disinfection criteria under LT2ESWTR and maintain bromate formation below $0.005 \mathrm{mg} / \mathrm{L}$, at the same time. This applies especially for facilities were chlorine-resistant microorganisms such as Cryptosporidium necessitate treatment [19, 26, 28, 29]. 
The process in which $\mathrm{BrO}_{3}{ }^{-}$is formed during ozonation consists of two phases: a quick and a slow initiated by $\mathrm{HO}^{\bullet}$ and $\mathrm{O}_{3}$ respectively [30]. These mechanistic steps have been extensively studied and unveiled by von Gunten's research group and have been illustrated as a series of bimolecular reactions (Figure 1) [8, 30, 31]. The 4 major steps that lead to $\mathrm{BrO}_{3}^{-}$formation begin with $\mathrm{O}_{3}$ oxidizing bromide $\left(\mathrm{Br}^{-}\right)$to hypobromite $\left(\mathrm{BrO}^{-}\right)$or hypobromous acid ( $\mathrm{HBrO}$ ), depending on the solution $\mathrm{pH}$. Then, $\mathrm{HBrO} / \mathrm{OBr}^{-}$is oxidized by $\mathrm{HO}^{\bullet}$ to $\mathrm{BrO}^{\bullet}$, followed by a disproportionation reaction $\left(2 \mathrm{BrO}^{\circ} \rightarrow \mathrm{BrO}^{-}+\mathrm{BrO}_{2}^{-}\right)$to give $\mathrm{BrO}_{2}{ }^{-}$and finally $\mathrm{O}_{3}$ oxidizes the latter ion to $\mathrm{BrO}_{3}{ }^{-}$[8]. A secondary pathway where $\mathrm{HO}^{\circ}$ oxidizes bromide to its corresponding radical $\left(\mathrm{Br}^{\circ}\right)$, that either reacts with $\mathrm{O}_{3}$ or $\mathrm{HO}^{\bullet}$ to form $\mathrm{BrO}^{\bullet}$ or $\mathrm{HOBr}^{-} \mathrm{BrO}^{-}$, respectively has also been reported. The oxidation of $\mathrm{HBrO} / \mathrm{BrO}^{-}$can also occur with $\mathrm{O}_{3}$ but at lower rates [8]. Identification of the mechanistic steps of $\mathrm{BrO}_{3}^{-}$ formation was crucial because it revealed its rate limiting steps and consequently assisted in adopting practices that can significantly reduce $\mathrm{BrO}_{3}^{-}$formation.

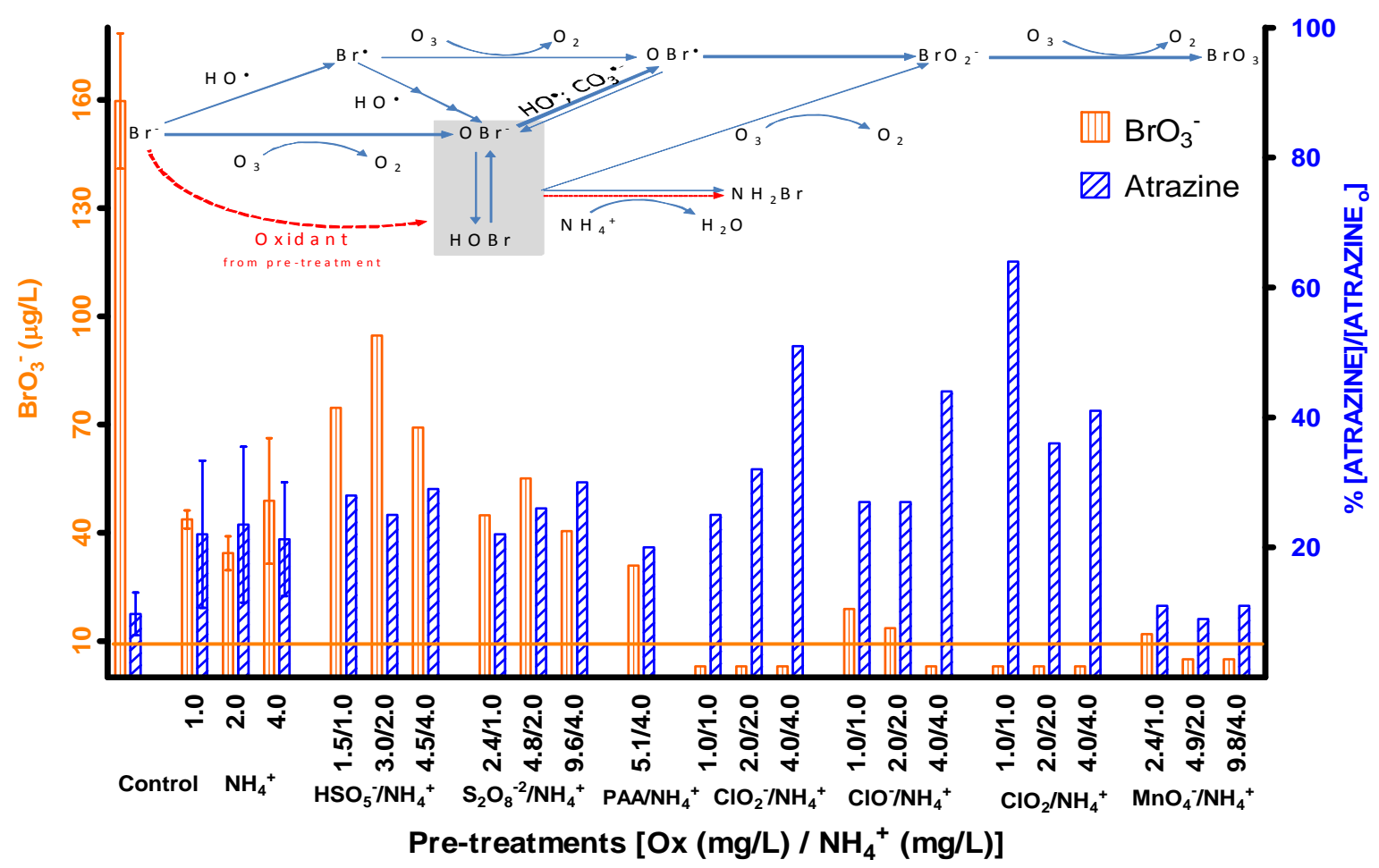

Figure 1: Effect of pre-treatment reagent pairs and concentrations [Oxidant (mg/L)/ $\mathrm{NH}_{4}{ }^{+}(\mathrm{mg} / \mathrm{L})$ ] on $\mathrm{BrO}_{3}{ }^{-}$formation (left axis) and remaining atrazine (right axis) during ozonation. Experimental conditions: $\mathrm{O}_{3}=3.5 \mathrm{mg} / \mathrm{L} ; \mathrm{Br}^{-}=100 \mu \mathrm{g} / \mathrm{L} ; \mathrm{Atrazine}_{\mathrm{o}}=200 \mu \mathrm{g} / \mathrm{L} ; \mathrm{NH}_{4}{ }^{+}=$ 1.0, 2.0, 4.0, mg/L; $\left[\mathrm{NH}_{4}^{+}\right] /\left[\mathrm{Br}^{-}\right]=44,88,178 ;[\mathrm{Ox}]=15,30,60 \mu \mathrm{M} ;[\mathrm{Ox}] /[\mathrm{Br}]=12,24,48 ; \mathrm{pH}=7.0$. (Methods std error: $\mathrm{SE}_{\mathrm{BrO3-}}=4.5$ $\left.\mu \mathrm{g} / \mathrm{L} ; \mathrm{SE}_{\mathrm{ATR}}=1.5 \mu \mathrm{g} / \mathrm{L}\right)$. Schematic inside Figure 1 is based on the mechanism discussed by $[8,53]$ and edited to include the effect of pre-treatments.

Based on this mechanistic understanding, several methods have been proposed to alter the water chemistry of the treated water in order to decrease the formation of bromate during the ozonation process. Depression of water $\mathrm{pH}$ to 6 shifts the equilibrium of $\mathrm{HBrO} / \mathrm{BrO}^{-}$towards $\mathrm{HBrO}$ which reacts slowly with $\mathrm{O}_{3}$ to form $\mathrm{BrO}_{3}^{-}$, therefore $\mathrm{BrO}_{3}{ }^{-}$formation is hindered [31,32]. This pre-treatment has successfully and cost-effectively been applied in water facilities [19]. However if the treated water has moderate to high alkalinity (ground-water) the $\mathrm{pH}$ adjustment cost may be prohibitive reaching 2 to 9 times ozone's operational cost [27, 28]. Another method is the $\mathrm{Cl}_{2} / \mathrm{NH}_{4}{ }^{+}$pre-treatment [31]. $\mathrm{Cl}_{2}$ is added prior to ozonation and oxidizes $\mathrm{Br}^{-}$to $\mathrm{HBrO} / \mathrm{BrO}^{-}$, which then reacts with added $\mathrm{NH}_{4}{ }^{+}$to form bromamine $\left(\mathrm{NH}_{2} \mathrm{Br}, k_{\mathrm{NH}^{+} / O 3}=8 \times 10^{7} \mathrm{M}^{-1} \mathrm{~s}^{-1}\right)[8,27,28,30,31]$. Since the latter molecule is not significantly oxidized by $\mathrm{O}_{3}\left(k_{\mathrm{NH} 2 \mathrm{Br} / \mathrm{O}}=40 \mathrm{M}^{-1} \mathrm{~s}^{-1}\right)$ [28], $\mathrm{BrO}_{3}{ }^{-}$formation is greatly reduced. However, this approach has some disadvantages including the formation of undesired chlorination by-products from the reaction of the added chlorine with organic matter and the need for sequential addition of $\mathrm{Cl}_{2}$ and $\mathrm{NH}_{4}{ }^{+}$since these 
chemicals readily react with each other to form chloramines. The most recently tested technology, is the coupling of photocatalysis to ozonation, which besides causing acceleration of the degradation rates of ECs, it can also limit bromate formation [33]. The effectiveness of these pre-treatments greatly depends on the quality of the treated water, including $\mathrm{pH}, \mathrm{NOM}$ and alkalinity since they affect the oxidation routes followed and contact times of $\mathrm{O}_{3}$ or $\mathrm{HO}^{\bullet}[28,31,34]$.

In our earlier study, [34], the abovementioned pre-treatments were evaluated for their efficiency to inhibit bromate formation while achieving one log atrazine (herbicide) removal from $\mathrm{Br}^{-}$spiked ground water from the DTU (Technical University of Denmark) Campus, which has high alkalinity $\left(\mathrm{HCO}_{3}{ }^{-}=332 \mathrm{mg} / \mathrm{L}, \mathrm{pH}_{\mathrm{o}}=7.4\right)$ and a considerable concentration of 'aged' natural organic matter (NOM; DOC $\sim 2.5 \mathrm{mg} / \mathrm{L}$ ) [34]. This water presents an exceptional challenge for $\mathrm{O}_{3}$ treatment because both $\mathrm{O}_{3}$ and $\mathrm{HO} \cdot$ are consumed by the NOM and high alkalinity, and consequently the required $\mathrm{O}_{3}$ dose for contaminant degradation is significantly increased along with $\mathrm{BrO}_{3}{ }^{-}$formation [35]. Our previous results indicated that a high $\mathrm{O}_{3}$ dose $(3.5 \mathrm{mg} / \mathrm{L})$ was needed to achieve $90 \%$ removal of atrazine from ground-water resulting in the formation of $130-170 \mu \mathrm{g} / \mathrm{L} \mathrm{BrO}_{3}{ }^{-}$. The $\mathrm{O}_{3}$-dose required to remove atrazine was unaffected even when ozone was applied as peroxone $\left(\mathrm{O}_{3} / \mathrm{H}_{2} \mathrm{O}_{2} 1: 3.5 \mathrm{w} / \mathrm{w}\right)$, though it limited $\mathrm{BrO}_{3}{ }^{-}$formation below the drinking water limit of $10 \mu \mathrm{g} / \mathrm{L}$. Depression of $\mathrm{pH}$ to 6 was proven insufficient to control $\mathrm{BrO}_{3}{ }^{-}$formation below the $10 \mu \mathrm{g} / \mathrm{L}$ limit in the ground water from the DTU Campus. Pretreatment with $\mathrm{Cl}_{2} / \mathrm{NH}_{4}{ }^{+}$reduced $\mathrm{BrO}_{3}{ }^{-}$formation close to the $10 \mu \mathrm{g} / \mathrm{L}$ limit; however, atrazine removal was reduced to below $75 \%$.

Based on the above, this co-operative study between Siemens Water Technologies and DTU aimed to investigate the efficiency of several oxidants commonly used in water treatment as replacements of $\mathrm{Cl}_{2}$ in the " $\mathrm{Cl}_{2} / \mathrm{NH}_{4}{ }^{+}$" pre-treatment for inhibiting $\mathrm{BrO}_{3}{ }^{-}$formation during ozonation to exceed the limit of $10 \mu \mathrm{g} / \mathrm{L}$. It was anticipated that these alternatives may be advantageous to $\mathrm{Cl}_{2}$, since they do not form chlororganic byproducts nor react directly with $\mathrm{NH}_{4}{ }^{+}$. Therefore, sodium hypochlorite $(\mathrm{NaClO})[22,36]$ and chlorine dioxide $\left(\mathrm{ClO}_{2}\right)[21$, 32], and the never before tested paracetic acid $\left(\mathrm{CH}_{3} \mathrm{COOOH}\right.$, PAA), potassium persulfate $\left(\mathrm{K}_{2} \mathrm{~S}_{2} \mathrm{O}_{8}\right)$, peroxymonosulfate $\left(\mathrm{KHSO}_{5}\right)$, and potassium permanganate $\left(\mathrm{KMnO}_{4}\right)$ were used in this study. Apart from monitoring $\mathrm{BrO}_{3}{ }^{-}$formation for each pre-treatment, the effect of the concentration of the oxidant and $\mathrm{NH}_{4}{ }^{+}$added were investigated. Also, the extent to which these pre-treatment affected atrazine removal during ozonation, was monitored. Atrazine was chosen as the model EC of this study, because it is a common treatment target for ozonation and its degradation is mainly attributed to the $\mathrm{HO}^{\bullet}$ formed during ozonation and less on direct ozonation $[4,12,34,37,38]$. In addition atrazine is part of the list of contaminants that the Water Framework Directive requires to be monitored in surface waters and its maximum allowable concentration in surface waters should not exceed $2.0 \mu \mathrm{g} / \mathrm{L}$ [39]. To the best of our knowledge, this is the first study that investigates the potential use of all these oxidants on the same source water, in order to control $\mathrm{BrO}_{3}{ }^{-}$formation during ozonation under the $10 \mu \mathrm{g} / \mathrm{L}$ limit, while achieving at the same one log atrazine removal.

\section{Materials and Methods}

\subsection{Reagents:}

Atrazine (ATR), sodium bromide $(\mathrm{NaBr})$, potassium permanganate $\left(\mathrm{KMnO}_{4}\right)$, sodium chlorite $\left(\mathrm{NaClO}_{2}\right)$, sodium hypochlorite $(\mathrm{NaClO})$, paracetic acid $\left(\mathrm{CH}_{3} \mathrm{COOOH}\right)$, peroxymonosulfate $\left(\mathrm{KHSO}_{5}\right)$, and potassium persulfate $\left(\mathrm{K}_{2} \mathrm{~S}_{2} \mathrm{O}_{8}\right)$ were purchased from Sigma-Aldrich and used as received. The treated tap water was first $\mathrm{pH}$ adjusted to 7 and then spiked with atrazine and $\mathrm{Br}^{-}$with final concentrations of $200 \mu \mathrm{g} / \mathrm{L}$ and $100 \mu \mathrm{g} / \mathrm{L}$, respectively. Details on the preparation of the water mixture and chlorine dioxide $\left(\mathrm{ClO}_{2}\right)$ stock solution are found in Antoniou and Andersen (2012) [34]. Details on the chemical composition of the DTU-tap water are found in Table S1. 


\subsection{Batch Experiments:}

In $120 \mathrm{~mL}$ blue cap borosilicate glass bottles, $100 \mathrm{~mL}$ of the water mixture were added and placed in a water bath at $15^{\circ} \mathrm{C}$. For the pre-treatment experiments, the oxidant was added first, allowing 15 min reaction time, $\mathrm{NH}_{4}^{+}$(as $\mathrm{NH}_{4} \mathrm{SO}_{4}$ ) was added next and allowed another $15 \mathrm{~min}$ of reaction time, before $\mathrm{O}_{3}$ addition ( 2 stages addition). For single stage addition, both the oxidant and $\mathrm{NH}_{4}{ }^{+}$were added at the same time $30 \mathrm{~min}$ before $\mathrm{O}_{3}$. Specific aliquots from the $\mathrm{O}_{3}$ stock solution were added and the bottles were left in a water bath to react overnight, at $\mathrm{T}=15^{\circ} \mathrm{C}$. The half-life of $1.7 \mathrm{mg} / \mathrm{L} \mathrm{O}_{3}$ in the same water matrix was measured at $2.74 \mathrm{~min}$, which means enough time was given for the reaction to be completed (estimated $\mathrm{O}_{3}$ contact time of $30 \mathrm{~min}$ ) [34]. Samples were taken the next day for the analysis of $\mathrm{BrO}_{3}{ }^{-}$and ATR. The error bars in the Figures represent the relative standard deviation (RSD) of at least 3 measurements.

\subsection{Quantification of $\mathrm{O}_{3}$ Initial Concentration:}

The initial $\mathrm{O}_{3}$ concentration of the saturated $\mathrm{O}_{3}$ solution was measured with a UV-Vis spectrophotometer at $\lambda=$ $260 \mathrm{~nm}$ in a quartz cuvette $(\lambda=1 \mathrm{~cm})$. By using the extinction co-efficient of $\mathrm{O}_{3}\left(\varepsilon_{260}=2900 \mathrm{~cm}^{-1} \cdot \mathrm{M}^{-1}\right)$ the molarity of the saturated solution was estimated. Specific volumes of the solution were added in each batch bottle to give a theoretical $\mathrm{O}_{3}$ concentration. The actual $\mathrm{O}_{3}$ concentration was quantified with the Indigo method [34, $40]$.

\subsection{Quantification of Initial Oxidant Concentration:}

The initial concentration of $\mathrm{ClO}^{-}, \mathrm{ClO}_{2}$ and $\mathrm{CH}_{3} \mathrm{COOO}^{-}$was measured photometrically with the HACH LANGE DR2800. $\mathrm{ClO}^{-}$was measured in the "free chlorine mode" by adding 3 drops of phosphate buffer $(\mathrm{pH}=2.0), 1$ drop of N,N-diethyl-p-phenylenediamine, DPD $(5 \mathrm{~g} / \mathrm{L})$ and $10 \mathrm{~mL}^{-}$of $\mathrm{ClO}^{-}$solution $(5 \mathrm{~mL}$ from concentrated stock in $1000 \mathrm{~mL}$ of Milli-Q water). $\mathrm{ClO}_{2}$ was measured in the " $\mathrm{ClO}_{2}$ mode" by following the same procedure as $\mathrm{ClO}^{-}$. Finally, $\mathrm{CH}_{3} \mathrm{COOO}^{-}$was measured in the $\mathrm{Cl}_{2}$ mode by adding 3 drops of potassium iodide $(5 \mathrm{~g} / \mathrm{L}) 1$ drop of DPD $(5 \mathrm{~g} / \mathrm{L})$ and $10 \mathrm{~mL}$ of dilute $\mathrm{CH}_{3} \mathrm{COOO}^{-}$solution.

\subsection{HPLC Analysis:}

Atrazine ( $\mathrm{FW}=215.69)$ was quantified with an Agilent 1100 Series HPLC equipped with a variable wavelength detector (VWD). A $\mathrm{C}_{18}$ column ( $46 \mathrm{~mm}$ x $15 \mathrm{~cm}, 5 \mu \mathrm{m}$ particle size) from Supelco Discovery was utilized. The eluent phase was 50:50 acetonitrile: $\mathrm{H}_{2} \mathrm{O}$, with a flow rate of $0.5 \mathrm{~mL} / \mathrm{min}, \mathrm{T}_{\text {column }}=25.5^{\circ} \mathrm{C}$ and the detector set at $\lambda$ $=220 \mathrm{~nm}$. Based on these conditions atrazine eluted at $\mathrm{RT}=8.2 \mathrm{~min}$. Calibration curves with standard solutions at $10-1000 \mu \mathrm{g} / \mathrm{L}$ were conducted and the method quantification limit was set at $5 \mu \mathrm{g} / \mathrm{L}$.

\subsection{Ion Chromatography Analysis:}

Determination of $\mathrm{BrO}_{3}{ }^{-}$concentration was performed via ion chromatography coupled with a post column reaction with $\mathrm{KI}$ that resulted in the formation of $\mathrm{I}_{3}{ }^{-}$which was measured in a UV detector (based on the method of Salhi et al., 1999 [41]. More information on the IC analysis can be retrieved from Antoniou and Andersen (2012) [34].

\section{Results and Discussion}

\subsection{Effect of pre-treatment type and added concentrations:}

The aim of this study was to find appropriate pre-treatments based on the " $\mathrm{Cl}_{2} / \mathrm{NH}_{4}{ }_{4}$ " pre-treatment so that the formation of carcinogenic $\mathrm{BrO}_{3}{ }^{-}$during ground-water ozonation is limited below $10.0 \mu \mathrm{g} / \mathrm{L}$ and to evaluate how much these pre-treatments affect atrazine removal. The applied concentrations of $\mathrm{NH}_{4}{ }^{+}$and oxidant $\left(\mathrm{Cl}_{2}\right)$ concentrations were within the range of literature reports [30,31]. $\mathrm{NH}_{4}{ }^{+}$was added at $1.0 \mathrm{mg} / \mathrm{L}$, which has a molar ratio to $\mathrm{Br}^{-}$equal to $\left[\mathrm{NH}_{4}{ }^{+}\right] /\left[\mathrm{Br}^{-}\right]=44$. The oxidants used, were added in the same molar concentrations as 
$\mathrm{Cl}_{2}$ starting at $1.0 \mathrm{mg} / \mathrm{L}$ equivalent $\mathrm{Cl}_{2}$, which is equal to $15.0 \mu \mathrm{M}$ and gives a molar ratio to bromide $[\mathrm{Ox}] /\left[\mathrm{Br}{ }^{-}\right]=$ 12. The doses for both $\mathrm{NH}_{4}{ }^{+}$and $\mathrm{Cl}_{2}$ were doubled and quadrupled to account for the added concentration effects. Overall, the oxidants $\mathrm{HSO}_{5}{ }^{-} \mathrm{S}_{2} \mathrm{O}_{8}{ }^{-2}, \mathrm{ClO}_{2}, \mathrm{ClO}_{2}{ }^{-}, \mathrm{ClO}^{-}, \mathrm{CH}_{3} \mathrm{COOO}^{-}$and $\mathrm{MnO}_{4}{ }^{-}$were tested under the abovementioned conditions. Initially, control experiments with $3.5 \mathrm{mg} / \mathrm{L} \mathrm{O}_{3}$ (as determined by the indigo method) were conducted in the batch reactors to account for the amount of $\mathrm{BrO}_{3}{ }^{-}$formed during treatment. $\mathrm{Next} \mathrm{NH}_{4}{ }^{+}$was added at molar concentrations equal to $\left[\mathrm{NH}_{4}{ }^{+}\right] /\left[\mathrm{Br}{ }^{-}\right]=44,88,178$ and allowed $15 \mathrm{~min}$ of reaction, and then 3.5 $\mathrm{mg} / \mathrm{L} \mathrm{O}_{3}$ were added and left to react overnight in a $15^{\circ} \mathrm{C}$ water bath. For the experiments with the oxidants, the oxidant was added first, allowed $15 \mathrm{~min}$ of reaction time, then $\mathrm{NH}_{4}{ }^{+}$was added and allowed another 15 min of reaction time before adding $3.5 \mathrm{mg} / \mathrm{L} \mathrm{O}_{3}$. The formation of $\mathrm{BrO}_{3}{ }^{-}$and reduction of the ATR's concentration were determined for all the experiments.

Figure 1 summarizes the results from the different pre-treatments on the $\mathrm{BrO}_{3}{ }^{-}$formation (left axis) and remaining atrazine (right axis). Ozonation of DTU tap water with $3.5 \mathrm{mg} / \mathrm{L} \mathrm{O}_{3}$, resulted in the formation of $160.0 \pm 19.0 \mathrm{BrO}_{3}{ }^{-} \mu \mathrm{g} / \mathrm{L}$. Based on the fact that the initial $\mathrm{Br}^{-}$concentration was $100 \mu \mathrm{g} / \mathrm{L}, 3.5 \mathrm{mg} / \mathrm{L} \mathrm{O}_{3}$ has completely transformed $\mathrm{Br}^{-}$to $\mathrm{BrO}_{3}{ }^{-}$. Addition of excess $\mathrm{NH}_{4}{ }^{+}$(which reacts with $\mathrm{HOBr} / \mathrm{OBr}$ to form $\mathrm{NH}_{2} \mathrm{Br}$ ), decreased $\mathrm{BrO}_{3}{ }^{-}$formation $\sim 75 \%$ compared to the $\mathrm{O}_{3}$ control, irrespective of the $\mathrm{NH}_{4}{ }^{+}$dosing. This means that lower concentrations than $1.0 \mathrm{mg} / \mathrm{L} \mathrm{NH}_{4}{ }^{+}\left(\left[\mathrm{NH}_{4}{ }^{+}\right] /\left[\mathrm{Br}^{-}\right]=44\right)$ could be efficiently used in DTU-water as they have been reported for lake water [30, 42]. It was expected that ammonia alone would not be able to completely control bromate below the $10 \mu \mathrm{g} / \mathrm{L}$ limit since it does not influence bromate formation with the radical pathway during the initial phase of ozonation [30]. As expected, $\mathrm{Cl}_{2} / \mathrm{NH}_{4}{ }^{+}$(as $\mathrm{ClO}^{-}$) greatly inhibited $\mathrm{BrO}_{3}{ }^{-}$formation compared to $\mathrm{O}_{3}$ alone. With increasing oxidant and $\mathrm{NH}_{4}{ }^{+}$concentrations, bromate formation reduced from 20 $\mu \mathrm{g} / \mathrm{L}$ to below the method detection limit (BDL). $\mathrm{ClO}_{2} / \mathrm{NH}_{4}{ }^{+}, \mathrm{ClO}_{2}{ }^{-} / \mathrm{NH}_{4}{ }^{+}$and $\mathrm{MnO}_{4}-\mathrm{NH}_{4}{ }^{+}$were the most efficient pre-treatments, since bromate formation was BDL for all oxidant concentrations (except for $15.0 \mu \mathrm{M} \mathrm{MnO}_{4}{ }^{-}$ which was on the limit). Besides $\mathrm{BrO}_{3}^{-}$, these oxidants can oxidize the active sites of NOM $[18,43]$ which is found in higher concentrations compared to the other matrix components $(2.5 \mathrm{mg} / \mathrm{L} \mathrm{DOC})$. Given that NOM is known to accelerate $\mathrm{O}_{3}$ decomposition [18], this has a direct impact on $\mathrm{O}_{3}$ exposure $(\mathrm{C} \cdot \mathrm{t})$, which becomes shorter, and results in decreased $\mathrm{BrO}_{3}{ }^{-}$formation. In addition, $\mathrm{NOM}$ competes with the contaminant for oxidation by the active species, therefore reducing the level of contaminant degradation. Since these oxidants were equally efficient for all the range of concentrations, it is implied that lower concentrations can be used and still control $\mathrm{BrO}_{3}{ }^{-}$formation below the set drinking water limit. The oxidants $\mathrm{HSO}_{5}{ }^{-}$and $\mathrm{S}_{2} \mathrm{O}_{8}{ }^{-2}$ that follow free radical mechanisms $\left(\mathrm{SO}_{4}{ }^{-}\right.$and $\mathrm{HO}^{\circ}$ ) for oxidation $[44,45]$, did not perform as well as expected with $\mathrm{NH}_{4}{ }^{+}$, especially $\mathrm{HSO}_{5}{ }^{-}$which performed worse than $\mathrm{NH}_{4}{ }^{+}$alone. One possible explanation could be that the reaction time was not sufficient for the oxidants to effectively oxidize $\mathrm{Br}^{-}$to $\mathrm{OBr}^{-}$, but longer reaction times would be technically impractical. Since the inhibition of $\mathrm{BrO}_{3}{ }^{-}$formation, relies on the efficiency of the oxidant to convert $\mathrm{Br}^{-}$to $\mathrm{OBr}^{-}$ prior to ozonation, it is apparent that $\mathrm{HSO}_{5}{ }^{-}$and $\mathrm{S}_{2} \mathrm{O}_{8}{ }^{-2}$ necessitate either additional reaction time or further catalytic activation to convert them into oxidizing radical species $[44,45]$. The increase of $\mathrm{BrO}_{3}{ }^{-}$concentration with $\mathrm{HSO}_{5}{ }^{-} / \mathrm{NH}_{4}{ }^{+}$could be attributed to $\mathrm{HO}^{-}$formed during its decomposition that enhance the radical based oxidation route of $\mathrm{Br}^{-} . \mathrm{CH}_{3} \mathrm{COOO}^{-}$had the same efficiency on $\mathrm{BrO}_{3}{ }^{-}$formation as $\mathrm{NH}_{4}{ }^{+}$, which means that it did not cause notable oxidation of $\mathrm{Br}^{-}$. Overall, the effectiveness on inhibiting $\mathrm{BrO}_{3}{ }^{-}$formation followed the order of: $\mathrm{KMnO}_{4} / \mathrm{NH}_{4}^{+}=\mathrm{ClO}_{2} / \mathrm{NH}_{4}{ }^{+}=\mathrm{ClO}_{2}{ }^{-} / \mathrm{NH}_{4}{ }^{+}>\mathrm{NaClO} / \mathrm{NH}_{4}{ }^{+}>\mathrm{NH}_{4}{ }^{+}>\mathrm{CH}_{3} \mathrm{COOO}^{-} / \mathrm{NH}_{4}{ }^{+}>\mathrm{S}_{2} \mathrm{O}_{8}^{-2} / \mathrm{NH}_{4}^{+}>\mathrm{HSO}_{5}{ }^{-}$ $/ \mathrm{NH}_{4}^{+}$.

The right axis of Figure 1, depicts the remaining atrazine concentration following the different pre-treatments and ozonation. Based on our previous studies [34], an $\mathrm{O}_{3}$ concentration of $3.5 \mathrm{mg} / \mathrm{L}$ was adequate to remove atrazine $(90.3 \% \pm 3.0 \%)$ and was used as the $\mathrm{O}_{3}$ delivered concentration throughout this study. The presence of $\mathrm{NH}_{4}{ }^{+}$reduced atrazine removal to $78.0 \pm 8.0 \%$. This may be attributed to the consumption of $\mathrm{O}_{3}$ by reacting with $\mathrm{NH}_{4}{ }^{+}$instead (as $\mathrm{NH}_{3}, k_{O 3, N H 3}=20.0 \pm 2.0 \mathrm{M}^{-1} \mathrm{~s}^{-1}$ [46], $k_{O H, N H 3}=1.0 \pm 0.1 \cdot 10^{8} \mathrm{M}^{-1} \mathrm{~s}^{-1}$ [47]. Though at $\mathrm{pH}=7.0$ only $0.22-0.88 \mu \mathrm{mol} / \mathrm{L}$ of ammonia are present as $\mathrm{NH}_{3(\text { aq })}\left(\mathrm{pka}_{\mathrm{NH} 4+}=9.3,\left[\mathrm{NH}_{4}{ }^{+}\right]_{0}=5.5-22.0 \mu \mathrm{mol} / \mathrm{L}\right)$, since atrazine concentration is $0.09 \mu \mathrm{mol} / \mathrm{L}\left(k_{A T R, O 3}=6.0-6.3 \mathrm{M}^{-1} \mathrm{~s}^{-1} \& k_{A T R, H O}=2.5-3.0 \cdot 10^{9} \mathrm{M}^{-1} \mathrm{~s}^{-1}\right)$ [38], $\mathrm{NH}_{3(a q)}$ becomes a 
significant competitor for both $\mathrm{O}_{3}$ and $\mathrm{HO}^{*}$ degradation. The effect of the presence of $\mathrm{NH}_{4}^{+}$on atrazine removal is noticeable because the latter is primarily removed through reaction with $\mathrm{HO}^{\bullet}$ formed through $\mathrm{O}_{3}$ decomposition.

$\mathrm{NH}_{4}{ }^{+}$was not the only pre-treatment that inhibited atrazine removal. In fact, $\mathrm{HSO}_{5}{ }^{-} / \mathrm{NH}_{4}{ }^{+}$and $\quad \mathrm{S}_{2} \mathrm{O}_{8}{ }^{-2} / \mathrm{NH}_{4}{ }^{+}$ and $\mathrm{CH}_{3} \mathrm{COOO}^{-} / \mathrm{NH}_{4}^{+}$inhibited atrazine removal in the same range as $\mathrm{NH}_{4}^{+}$. It is believed that these oxidants under our experimental conditions were not sufficiently activated to form the radical that can oxidize bromide to bromate and therefore, the effect on atrazine removal is mainly attributed to the presence of $\mathrm{NH}_{4}{ }^{+}$. Pre-treatments with $\mathrm{ClO}_{2}{ }^{-} / \mathrm{NH}_{4}{ }^{+}, \mathrm{ClO}_{2} / \mathrm{NH}_{4}{ }^{+}$and $\mathrm{ClO}^{-} / \mathrm{NH}_{4}{ }^{+}$affected atrazine removal the most, with the efficiencies varying between 35.0-75.0\% for the different oxidant concentrations. $\mathrm{MnO}_{4}{ }^{-} / \mathrm{NH}_{4}{ }^{+}$, besides controlling $\mathrm{BrO}_{3}{ }^{-}$formation at the $10 \mu \mathrm{g} / \mathrm{L}$ limit did not influence atrazine removal $(90.0 \pm 1.0 \%)$ for all the oxidant concentrations. The reproducibility of the experiments was tested in a separate experiment summarized in the supplementary information document (S.I., Figure S1).

\subsection{Pre-treatment with $\mathrm{ClO}_{2}, \mathrm{ClO}_{2}{ }^{-}$and $\mathrm{MnO}_{4}{ }^{-}$: Effect of oxidant and $\mathrm{NH}_{4}{ }^{+}$concentration and addition} stages:

With $\mathrm{ClO}_{2} / \mathrm{NH}_{4}{ }^{+}$and $\mathrm{ClO}_{2}{ }^{-} / \mathrm{NH}_{4}{ }^{+}$and $\mathrm{MnO}_{4}{ }^{-} / \mathrm{NH}_{4}{ }^{+}$exhibiting the highest potential for preventing $\mathrm{BrO}_{3}{ }^{-}$ formation during ozonation, these oxidants were further investigated. Figure 1, indicates that lower oxidant and $\mathrm{NH}_{4}{ }^{+}$concentrations could potentially be used, while reaching the treatment goals. Therefore, the oxidant concentrations were reduced to doses between 1.5 and $15 \mu \mathrm{M}\left([\mathrm{Ox}] /\left[\mathrm{Br}^{-}\right]=1.2-12.0\right)$, while $\mathrm{NH}_{4}{ }^{+}$was kept at 1.0 $\mathrm{mg} / \mathrm{L}\left(\left[\mathrm{NH}_{4}{ }^{+}\right] /\left[\mathrm{Br}{ }^{-}\right]=44\right)$. Based on the results shown in Figure $2 \mathrm{~A}$, for $\mathrm{ClO}_{2} / \mathrm{NH}_{4}{ }^{+}$and $\mathrm{ClO}_{2}{ }^{-} / \mathrm{NH}_{4}{ }^{+}, \mathrm{BrO}_{3}{ }^{-}$ formation was approximately $22.0 \mu \mathrm{g} / \mathrm{L}$ for all concentrations except for $0.1 \mathrm{mg} / \mathrm{L} \mathrm{ClO}_{2}^{-}(\mathrm{C}=1.5 \mu \mathrm{M})$ which gave $30 \pm 7 \mu \mathrm{g} / \mathrm{L} \mathrm{BrO}_{3}^{-}$. For these two oxidants, $\mathrm{BrO}_{3}{ }^{-}$formation was better controlled when the higher range of oxidant and $\mathrm{NH}_{4}^{+}$concentrations were used (Figure 1). In the case of $\mathrm{MnO}_{4}{ }^{-} / \mathrm{NH}_{4}{ }^{+}$, only at $2.4 \mathrm{MnO}_{4}^{-} \mathrm{mg} / \mathrm{L} \mathrm{BrO}_{3}^{-}$ formation was below the $10.0 \mu \mathrm{g} / \mathrm{L}$ limit while for the remaining concentrations it was $\sim 18 \mu \mathrm{g} / \mathrm{L}$. On the other hand, with reduced oxidant concentrations and $1.0 \mathrm{mg} / \mathrm{L} \mathrm{NH}_{4}{ }^{+}$, atrazine removal greatly improved for $\mathrm{ClO}_{2} / \mathrm{NH}_{4}{ }^{+}$ and $\mathrm{ClO}_{2}{ }^{-} / \mathrm{NH}_{4}{ }^{+}$. For $\mathrm{ClO}_{2}{ }^{-}$it was $85.0 \%$ for all oxidant concentrations, while for $\mathrm{ClO}_{2}$, atrazine removal reduced with increasing oxidant concentration from $85 \%$ to $75 \%$. As far as $\mathrm{MnO}_{4}{ }^{-} / \mathrm{NH}_{4}{ }^{+}$, the efficiency reached almost $90 \%$ for all oxidant concentrations (Figure $2 \mathrm{~A}$ ). When it comes to atrazine removal, the effect of $\mathrm{ClO}_{2}$ and $\mathrm{ClO}_{2}{ }^{-}$ with $\mathrm{O}_{3}$ is not additive since they are exerting an ozone demand (as explained in Section 3.4). Also, when used alone $\mathrm{O}_{3}$ and $\mathrm{MnO}_{4}^{-}$react very slowly with atrazine $\left(k_{O 3}=6.0-6.3 \mathrm{M}^{-1} \mathrm{~s}^{-1}[38] ; k_{\mathrm{MnO} 4}=1.16 \mathrm{M}^{-1} \mathrm{~s}^{-1}\right.$ [48]), while $\mathrm{ClO}_{2}$ and $\mathrm{ClO}_{2}{ }^{-}$have been reported not to react [49]. Based on our results, $\mathrm{O}_{3}$ and $\mathrm{MnO}_{4}{ }^{-}$can co-exist without inhibiting each other's oxidative action on atrazine and $\mathrm{Br}^{-}$, respectively. On the contrary, $\mathrm{ClO}_{2}$ and $\mathrm{ClO}_{2}^{-}$greatly affect the oxidation capacity of $\mathrm{O}_{3}$. One possible reason (explained in greater detail later on and in Figure 4) could be the preferential reaction of $\mathrm{ClO}_{2}{ }^{-}$with $\mathrm{O}_{3}$ to form $\mathrm{ClO}_{2}$ which limits $\mathrm{O}_{3}$ exposure and thus $\mathrm{HO}^{\circ}$ production. When $\mathrm{ClO}_{2}$ and $\mathrm{ClO}_{2}{ }^{-}$are reduced, the loss of $\mathrm{O}_{3}$ is also reduced and more $\mathrm{O}_{3}$ (and therefore $\mathrm{HO}^{\circ}$ ) are available for atrazine removal. Based on this experiment, it was decided to use $0.6 \mathrm{mg} / \mathrm{L} \mathrm{ClO}_{2}, 0.6 \mathrm{mg} / \mathrm{L} \mathrm{ClO}_{2}{ }^{-}$and 1.4 and $2.4 \mathrm{mg} / \mathrm{L} \mathrm{MnO}_{4}{ }^{-}$as the optimum oxidant concentrations for the remaining experiments.

Since the effect of reduced oxidant concentration was beneficial towards the treatment goals, the effect of reduced $\mathrm{NH}_{4}{ }^{+}$concentration was tested next at, the previously determined, reduced oxidant concentrations. The new $\mathrm{NH}_{4}{ }^{+}$concentration was 0.1 and $0.4 \mathrm{mg} / \mathrm{L}$ (equal to $\left[\mathrm{NH}_{4}{ }^{+}\right] /\left[\mathrm{Br}^{-}\right]=4.4 ; 17.6$ ). Even though, the added $\mathrm{NH}_{4}{ }_{4}$ is significantly less, it is still in excess compared to $\mathrm{Br}^{-}$, and should be sufficient for the reaction of $\mathrm{BrO}^{-}$to $\mathrm{NH}_{2} \mathrm{Br}$. Based on the results depicted in Figure $2 \mathrm{~B}$, for the $\mathrm{ClO}_{2} / \mathrm{NH}_{4}{ }^{+}$pre-treatment, $\mathrm{NH}_{4}{ }^{+}$reduction to 0.1 $\mathrm{mg} / \mathrm{L}$ reduced $\mathrm{BrO}_{3}{ }^{-}$formation to $10.0 \mu \mathrm{g} / \mathrm{L}$, while at the same time atrazine removal was $87.0 \%$. For $0.4 \mathrm{mg} / \mathrm{L}$ $\mathrm{NH}_{4}{ }^{+}$, the efficiency for $\mathrm{BrO}_{3}{ }^{-}$formation was $\mathrm{BDL}$ and atrazine removal 82.0\%. $\mathrm{For}_{\mathrm{ClO}}{ }_{2}{ }^{-} \mathrm{NH}_{4}{ }^{+}, \mathrm{BrO}_{3}{ }^{-}$formation increased to $40 \mu \mathrm{g} / \mathrm{L}$ at $0.1 \mathrm{mg} / \mathrm{L} \mathrm{NH}_{4}{ }^{+}$and decreased BDL for $0.4 \mathrm{NH}_{4}{ }^{+} \mathrm{mg} / \mathrm{L}$, while atrazine removal was at $90.0 \%$ with $0.1 \mathrm{mg} / \mathrm{L} \mathrm{NH}_{4}{ }^{+}$, and decreased to $85 \%$ when $0.4 \mathrm{mg} / \mathrm{L} \mathrm{NH}_{4}{ }^{+}$were used. For $\mathrm{MnO}_{4}{ }^{-} / \mathrm{NH}_{4}{ }^{+}, 1.4$ and 2.4 $\mathrm{mg} \mathrm{MnO}_{4}{ }^{-} / \mathrm{L}$ were used with the low $\mathrm{NH}_{4}{ }^{+}$concentrations since they had similar efficiencies (Figure $2 \mathrm{~A}$ ). From the results depicted in Figure 2B, it is determined that $0.4 \mathrm{mg} / \mathrm{L}_{\text {of }} \mathrm{NH}_{4}^{+}$are needed for $\mathrm{MnO}_{4}{ }^{-}$to be effective in controlling $\mathrm{BrO}_{3}{ }^{-}$formation. Also, $1.4 \mathrm{mg} / \mathrm{L}$ of $\mathrm{MnO}_{4}{ }^{-}$was not sufficient to oxidize $\mathrm{Br}^{-}$to $\mathrm{OBr}^{-}$, and therefore, at 
least $2.4 \mathrm{mg} \mathrm{MnO}_{4}{ }^{-} / \mathrm{L}$ should be used. Atrazine removal maintained around $87.0 \%$ irrespective of the experimental conditions.

A

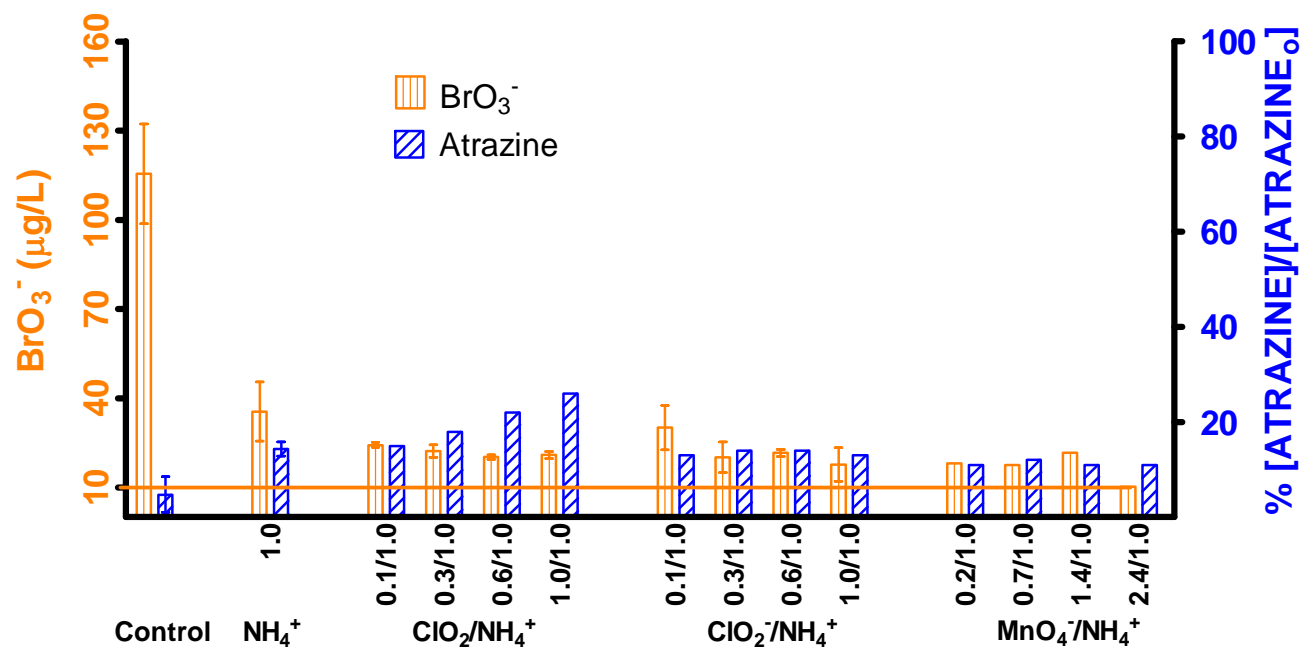

Pre-treatments [Ox (mg/L) / $\left.\mathrm{NH}_{4}^{+}(\mathrm{mg} / \mathrm{L})\right]$

B

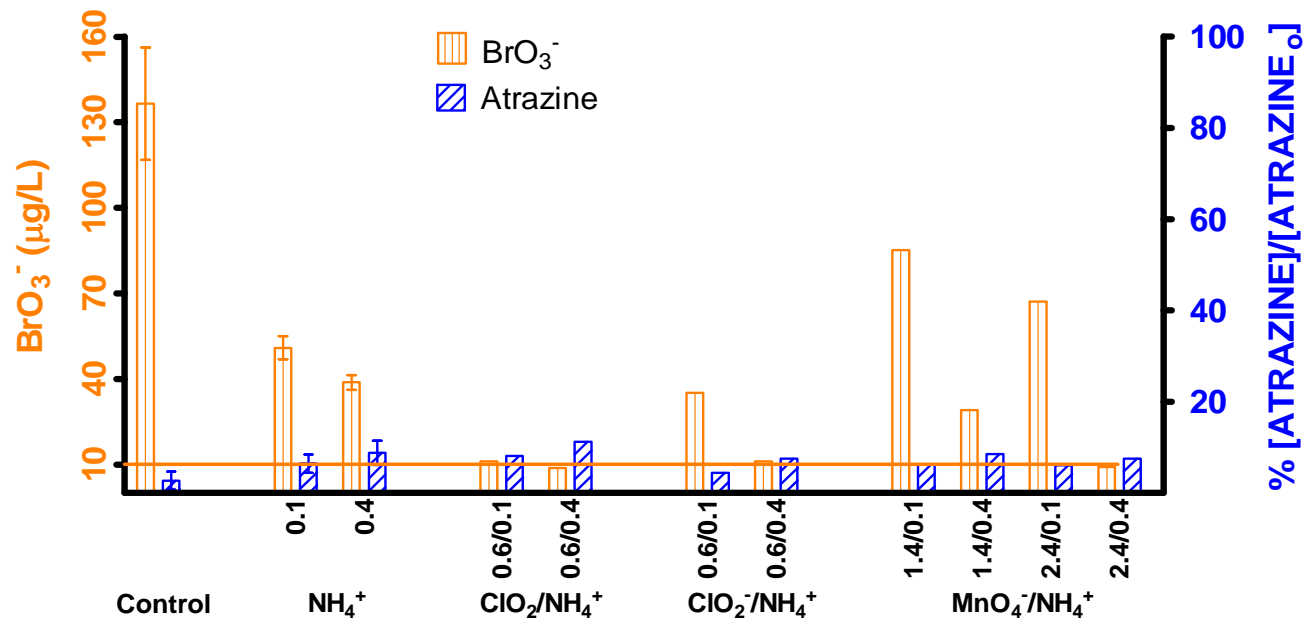

Pre-treatments [Ox $\left.(\mathrm{mg} / \mathrm{L}) / \mathrm{NH}_{4}{ }^{+}(\mathrm{mg} / \mathrm{L})\right]$

Figure 2A: Effect of reduced oxidant doses $\left(\mathrm{ClO}_{2}\right.$ and $\mathrm{ClO}_{2}^{-}$and $\left.\mathrm{MnO}_{4}{ }^{-}\right)$on $\mathrm{BrO}_{3}^{-}$formation and remaining atrazine concentration. Experimental conditions: $\mathrm{O}_{3}=3.5 \mathrm{mg} / \mathrm{L} ; \mathrm{Br}^{-}=100 \mu \mathrm{g} / \mathrm{L}^{-} \mathrm{ATR}_{\mathrm{o}}=200 \mu \mathrm{g} / \mathrm{L}^{-} \mathrm{NH}_{4}{ }^{+}=1.0 \mathrm{mg} / \mathrm{L}^{2}\left[\mathrm{NH}_{4}{ }^{+}\right] /[\mathrm{Br}]=44.0 ;[\mathrm{Ox}]=1.5,4.5,9.0,15.0$ $\mu \mathrm{M} ;[\mathrm{Ox}] /[\mathrm{Br}]=1.2,3.6,7.2,12.0 . ; \mathrm{pH}=7.0$. 2B: Effect of reduced ammonia doses on $\mathrm{BrO}_{3}{ }^{-}$formation and remaining atrazine concentration for $\mathrm{ClO}_{2}$ and $\mathrm{ClO}_{2}^{-}$at $[\mathrm{Ox}] /\left[\mathrm{Br}^{-}\right]=7.2$ and $\mathrm{MnO}_{4}^{-}$at $[\mathrm{Ox}] /\left[\mathrm{Br}^{-}\right]=7.2,12.0$. Experimental conditions: $\mathrm{O}_{3}=3.5 \mathrm{mg} / \mathrm{L}^{-} \mathrm{Br}^{-}=100$ $\mu \mathrm{g} / \mathrm{L} ; \mathrm{ATR}_{\mathrm{o}}=200 \mu \mathrm{g} / \mathrm{L} ; \mathrm{NH}_{4}{ }^{+}=0.1,0.44 \mathrm{mg} / \mathrm{L} ;\left[\mathrm{NH}_{4}^{+}\right] /\left[\mathrm{Br}^{-}\right]=4.4,17.6 ;[\mathrm{Ox}]=9.0,15.0 \mu \mathrm{M} ;[\mathrm{Ox}] /\left[\mathrm{Br}^{-}\right]$= 7.2, 12; $\mathrm{pH}=7.0$.

To summarize, the optimum concentrations to reach the treatment goals are $0.6 \mathrm{mg} / \mathrm{L} \mathrm{ClO}_{2} \quad\left([\mathrm{Ox}] /\left[\mathrm{Br}^{-}\right]=7.2\right)$ with $0.1 \mathrm{mg} / \mathrm{L} \mathrm{NH}_{4}^{+}\left(\left[\mathrm{NH}_{4}^{+}\right] /\left[\mathrm{Br}^{-}\right]=4.4\right) ; 0.6 \mathrm{mg} / \mathrm{L} \mathrm{ClO}_{2}^{-}\left([\mathrm{Ox}] /\left[\mathrm{Br}^{-}\right]=7.2\right)$ with $0.4 \mathrm{mg} / \mathrm{L} \mathrm{NH}_{4}^{+}\left(\left[\mathrm{NH}_{4}^{+}\right] /\left[\mathrm{Br}^{-}\right]=\right.$ $4.4)$ and $2.4 \mathrm{mg} / \mathrm{L} \mathrm{MnO}_{4}^{-}\left([\mathrm{Ox}] /\left[\mathrm{Br}^{-}\right]=7.2\right)$ with $0.4 \mathrm{mg} / \mathrm{L} \mathrm{NH}_{4}{ }^{+}\left(\left[\mathrm{NH}_{4}^{+}\right] /\left[\mathrm{Br}^{-}\right]=4.4\right)$. 
Simultaneous (single stage) addition of the oxidant and $\mathrm{NH}_{4}{ }^{+}$is technically more advantageous than two stage addition because it reduces treatment time and thus tank size in the waterworks. To test whether the effectiveness of $\mathrm{ClO}_{2}$, $\mathrm{ClO}_{2}^{-}$and $\mathrm{MnO}_{4}{ }^{-}$ with $\mathrm{NH}_{4}{ }^{+}$to inhibit $\mathrm{BrO}_{3}{ }^{-}$formation is affected by the addition stages, experiments with [Ox]/[Br]= 7.2 and $1.0 \mathrm{mg} / \mathrm{L} \mathrm{NH}_{4}{ }^{+}$were performed. The results on $\mathrm{BrO}_{3}^{-}$formation and atrazine removal (Figure 3 ) do not vary statistically (t-testing, 95\% confidence) and therefore, pre-treatments with these oxidants, in contrast to $\mathrm{Cl}_{2} / \mathrm{NH}_{4}{ }^{+}$, are proven not to be dependent on the addition stages.

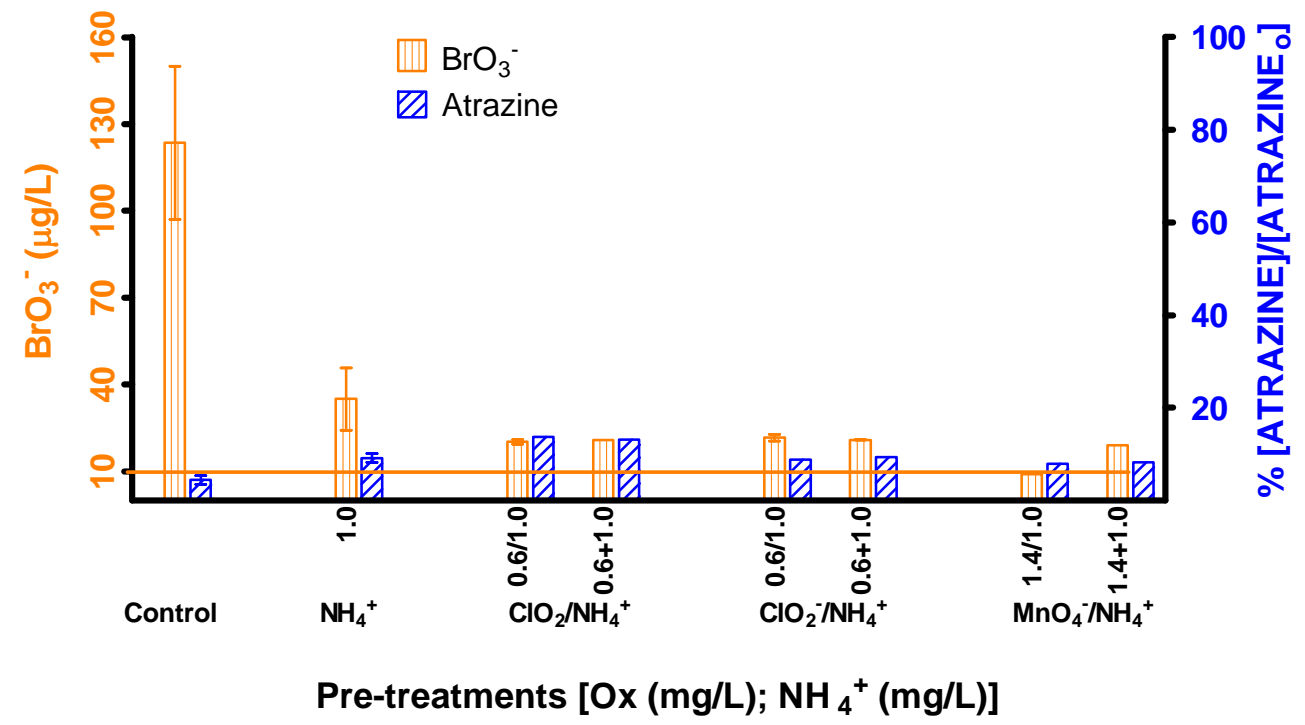

Figure 3: Effect of oxidants $\left(\mathrm{ClO}_{2}\right.$ and $\mathrm{ClO}_{2}{ }^{-}$and $\left.\mathrm{MnO}_{4}{ }^{-}\right)$and $\mathrm{NH}_{4}{ }^{+}$addition for single $\left(\mathrm{Ox}+\mathrm{NH}_{4}^{+}, \mathrm{t}=30\right.$ min) and two stage addition (Ox $\left./ \mathrm{NH}_{4}{ }^{+}, \mathrm{t}=15+15 \mathrm{~min}\right)$. Experimental conditions: $\mathrm{O}_{3}=3.5 \mathrm{mg} / \mathrm{L} ; \mathrm{Br}^{-}=100 \mu \mathrm{g} / \mathrm{L} ; \mathrm{ATR}_{\mathrm{o}}=200 \mu \mathrm{g} / \mathrm{L} ; \mathrm{NH}_{4}{ }^{+}=1.0 \mathrm{mg} / \mathrm{L} ;\left[\mathrm{NH}_{4}{ }^{+}\right] /[\mathrm{Br}]=44 ;[\mathrm{Ox}]$ $=9.0 \mu \mathrm{M} ;[\mathrm{Ox}] /[\mathrm{Br}]=7.2 ; \mathrm{pH}=7.0$.

\subsection{Pre-treatment with $\mathrm{ClO}_{2}, \mathrm{ClO}_{2}^{-}$, and $\mathrm{MnO}_{4}{ }_{4}^{-}$in the absence of $\mathrm{NH}_{4}^{+}$:}

In an effort to unveil the mechanisms that inhibit $\mathrm{BrO}_{3}^{-}$formation with $\mathrm{ClO}_{2}, \mathrm{ClO}_{2}^{-}$, and $\mathrm{MnO}_{4}^{-}$, experiments in the absence of $\mathrm{NH}_{4}{ }^{+}$were conducted. Concentrations of $0.6 \mathrm{mg} / \mathrm{L}$ were used for $\mathrm{ClO}_{2}, \mathrm{ClO}_{2}{ }^{-}$, $\left([\mathrm{Ox}] /\left[\mathrm{Br}^{-}\right]=7.2\right)$ and $2.4 \mathrm{mg} / \mathrm{L} \mathrm{MnO}_{4}{ }^{-}\left([\mathrm{Ox}] /\left[\mathrm{Br}^{-}\right]=12\right)$. Each oxidant was left to react for $15 \mathrm{~min}$ prior to the addition of $3.5 \mathrm{mg} / \mathrm{L}$ $\mathrm{O}_{3}$. It is apparent from Figure 4 that the absence of $\mathrm{NH}_{4}{ }^{+}$resulted in a drastic increase of $\mathrm{BrO}_{3}{ }^{-}$formation for all the oxidants (compared to Figure 2B) and especially for $2.4 \mathrm{mg} / \mathrm{L} \mathrm{MnO}_{4}{ }^{-}$, that yielded the same $\mathrm{BrO}_{3}{ }^{-}$ concentration as the $\mathrm{O}_{3}$ control.

There are two more studies in the literature in which addition of permanganate in the absence of ammonia was investigated as a pre-treatment to ozonation [50-51]. Dong et al. (2010) reported that addition of $1.0 \mathrm{mg} / \mathrm{L}$ $\mathrm{KMnO}_{4}$ could decrease $\mathrm{BrO}_{3}{ }^{-}$formation by $26 \%$ in water containing $100 \mu \mathrm{g} / \mathrm{L}$ bromide, $5 \mathrm{mg} / \mathrm{L}$ humic acids, for an added $\mathrm{O}_{3}$ dose of $5.6 \mathrm{mg} / \mathrm{L}$ and reaction time of $30 \mathrm{~min}$. In the absence of humic acid an approximate $20 \%$ reduction of $\mathrm{BrO}_{3}{ }^{-}$formation was reported in similar reaction conditions [50]. Liu et al. (2014) also reported that $\mathrm{KMnO}_{4}$ alone can inhibit $\mathrm{BrO}_{3}{ }^{-}$formation for $0.4 \mathrm{mg} / \mathrm{L} \mathrm{O}{ }_{3}$ without providing further explanation on their findings [51]. These results differ from the findings of our study, where absolutely no inhibition of bromate formation by permanganate was achieved without the co-addition of ammonia. This may be explained by the differences in the experimental conditions between studies (water matrix, $\mathrm{O}_{3}$ dose). Dong et al. (2010) hypothesized that the observed decrease in bromate formation is caused by catalytic and reductive consumption of ozone by manganese oxides formed from $\mathrm{MnO}_{4}{ }^{-}$which compete with bromide for ozone. This suggested mechanism implies that removal of target chemicals for the ozone treatment, like atrazine in our study, would decrease by permanganate addition, but inhibition of atrazine removal was not observed in this study in the presence or absence of ammonia.

Addition of $\mathrm{ClO}_{2}$ and $\mathrm{ClO}_{2}^{-}$yielded $50.0 \mu \mathrm{g} / \mathrm{L}$ and $42.0 \mu \mathrm{g} / \mathrm{L}$ of $\mathrm{BrO}_{3}^{-}$, respectively. The results (Figure 4) confirmed the importance of $\mathrm{NH}_{4}{ }^{+}$for the pre-treatments to be effective in preventing $\mathrm{BrO}_{3}{ }^{-}$formation. In the absence of $\mathrm{NH}_{4}^{+}$, the in situ generated $\mathrm{OBr}^{-}$(from the oxidation of $\mathrm{ClO}_{2}, \mathrm{ClO}_{2}^{-}$, and $\mathrm{MnO}_{4}^{-}$) exclusively 
transforms to $\mathrm{BrO}_{3}{ }^{-}$with ozonation. Atrazine removal was less affected by the absence of $\mathrm{NH}_{4}{ }^{+}$and was $\sim 85.0 \%$ for $\mathrm{ClO}_{2}$ and $\mathrm{ClO}_{2}{ }^{-}$and $95.0 \%$ for $\mathrm{MnO}_{4}{ }^{-}$.

Figures

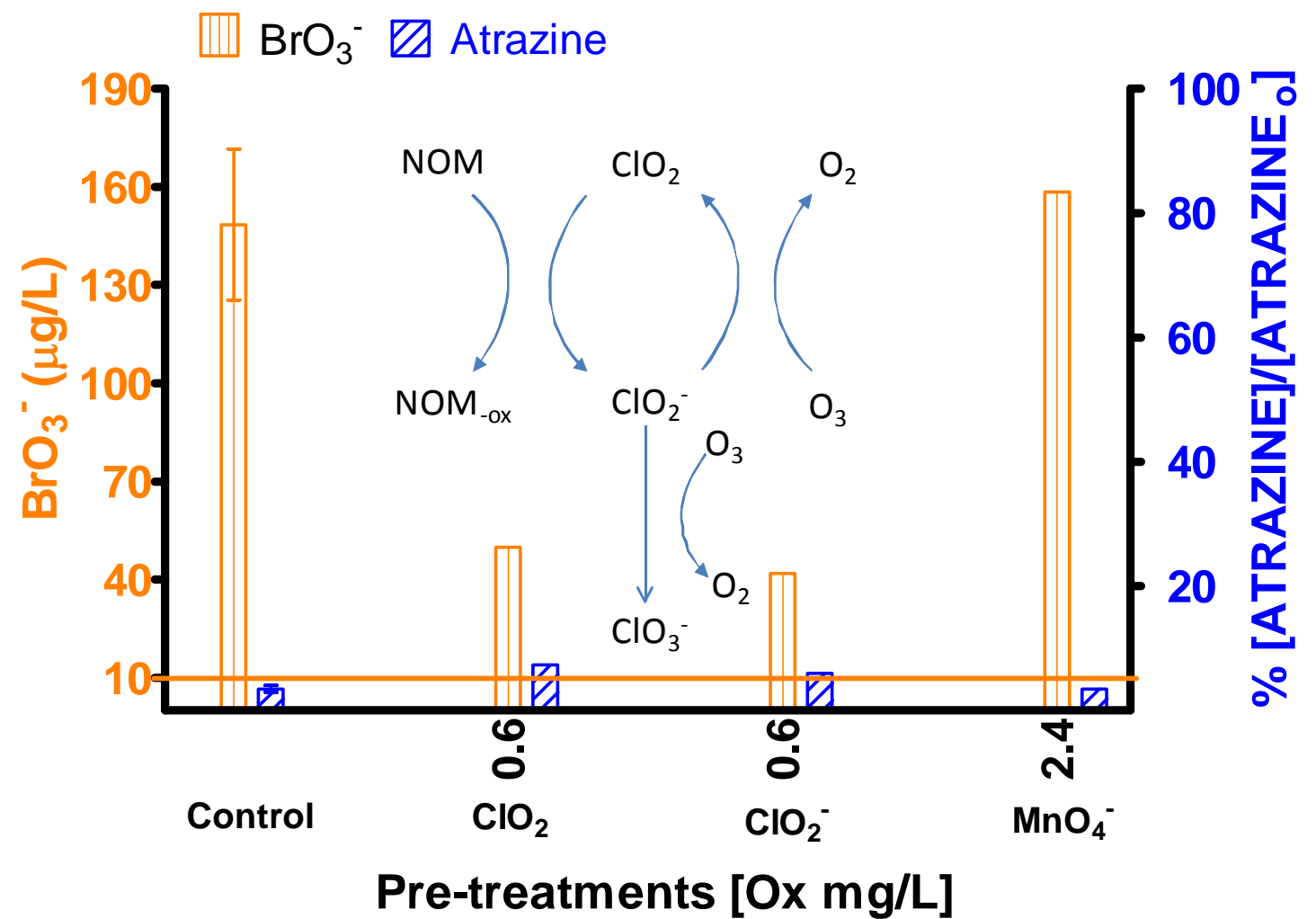

Figure 4: Pre-treatment with $\mathrm{ClO}_{2}, \mathrm{ClO}_{2}^{-}$, and $\mathrm{MnO}_{4}{ }^{-}$in the absence of $\mathrm{NH}_{4}^{+}$following ozonation. Experimental conditions: $\mathrm{O}_{3}=3.5$ $\mathrm{mg} / \mathrm{L} ; \mathrm{Br}^{-}=100 \mu \mathrm{g} / \mathrm{L} ; \mathrm{ATR}_{\mathrm{o}}=200 \mu \mathrm{g} / \mathrm{L} ;[\mathrm{Ox}]=9.0 \mu \mathrm{M} ;[\mathrm{Ox}] /\left[\mathrm{Br}^{-}\right]=7.2$. For $2.4 \mathrm{mg} / \mathrm{L} \mathrm{MnO}_{4}^{-},[\mathrm{Ox}]=15 \mu \mathrm{M} ;[\mathrm{Ox}] /[\mathrm{Br}]$ ] = 12; $\mathrm{pH}=7.0$.

\subsection{Proposed secondary mechanisms for $\mathrm{ClO}_{2}$ and $\mathrm{ClO}_{2}{ }^{-}$inhibition of $\mathrm{BrO}_{3}{ }^{-}$formation:}

Based on the findings of this study, side mechanisms that inhibit $\mathrm{BrO}_{3}{ }^{-}$formation are proposed (Figure 4). The main mechanism behind the inhibition of $\mathrm{BrO}_{3}^{-}$formation in the pre-treatments $\mathrm{ClO}_{2}, \mathrm{ClO}_{2}^{-}$, and $\mathrm{MnO}_{4}^{-}$with $\mathrm{NH}_{4}{ }^{+}$is:

Oxidant $+\mathrm{Br}^{-} \rightarrow \mathrm{BrO}^{-} ; \mathrm{BrO}^{-}+\mathrm{NH}_{4}^{+} \rightarrow \mathrm{NH}_{2} \mathrm{Br}$

However, the experiment with $\mathrm{ClO}_{2}, \mathrm{ClO}_{2}{ }^{-}$, and $\mathrm{MnO}_{4}{ }^{-}$in the absence of $\mathrm{NH}_{4}{ }^{+}$indicated the existence of another mechanism that affects $\mathrm{BrO}_{3}{ }^{-}$formation and atrazine removal (Figure 4). Prior to ozonation, $\mathrm{ClO}_{2}$ reacts with NOM and becomes $\mathrm{ClO}_{2}{ }^{-}$. The NOM in DTU-tap water reduces $0.6 \mathrm{mg} / \mathrm{L} \mathrm{ClO}_{2}$ to $\mathrm{ClO}_{2}{ }^{-}$almost instantaneously (unpublished data). Once the solution is ozonated, the added or in situ formed (from $\left.\mathrm{ClO}_{2}\right) \mathrm{ClO}_{2}^{-}$, rapidly reacts with $\mathrm{O}_{3}$ and produces $\mathrm{ClO}_{3}^{-}$(terminal reaction) or regenerates $\mathrm{ClO}_{2}$ (cyclic reaction). These reactions reduce the available $\mathrm{O}_{3}$ for oxidation of brominated species and therefore less $\mathrm{BrO}_{3}{ }^{-}$is formed. This is the reason why in the absence of $\mathrm{NH}_{4}{ }^{+}$with $\mathrm{ClO}_{2}$ and $\mathrm{ClO}_{2}{ }^{-}, \mathrm{BrO}_{3}{ }^{-}$formation is $31.0 \%$ and $26.0 \%$ of the $\mathrm{O}_{3}$ control, respectively. This experiment indicates that $\mathrm{MnO}_{4}{ }^{-}$did not follow a similar mechanism and therefore, $\mathrm{BrO}_{3}{ }^{-}$formation with $\mathrm{MnO}_{4}^{-}$pre-treatment in the absence of $\mathrm{NH}_{4}^{+}$was the same as the $\mathrm{O}_{3}$ control.

It was also observed, that pre-treatment with $\mathrm{ClO}_{2} / \mathrm{NH}_{4}{ }^{+}$required $0.1 \mathrm{mg} / \mathrm{L}$ of $\mathrm{NH}_{4}^{+}$to inhibit $\mathrm{BrO}_{3}{ }^{-}$formation while $\mathrm{ClO}_{2}{ }^{-}$required $0.4 \mathrm{mg} / \mathrm{L}$ of $\mathrm{NH}_{4}^{+}$, at the same molar concentration. This is likely due to the fact that $\mathrm{ClO}_{2}$ is a stronger oxidant that $\mathrm{ClO}_{2}^{-}$and it is able to oxidize $\mathrm{Br}^{-}$to $\mathrm{HOBr} / \mathrm{OBr}$, prior to ozonation. $\mathrm{ClO}_{2}{ }^{-}$can only initiate 
$\mathrm{Br}^{-}$oxidation when it is oxidized by $\mathrm{O}_{3}$ to $\mathrm{ClO}_{2}$ (Figure 4). Therefore, excess $\mathrm{NH}_{4}{ }^{+}$is required to insure conversion of $\mathrm{HOBr} / \mathrm{OBr}^{-}$to $\mathrm{NH}_{2} \mathrm{Br}$ (since this reaction is in competition with the others that lead to the further oxidation of $\mathrm{HOBr} / \mathrm{OBr}^{-}$to $\mathrm{BrO}_{2}^{-}$and $\mathrm{BrO}_{3}{ }^{-}$).

\subsection{Estimated cost of pretreatments:}

With the focus of this study placed on the feasibility of various pretreatments for $\mathrm{BrO}_{3}{ }^{-}$control during ozonation, the additional chemical cost at the optimum conditions of each pre-treatment was calculated, based on market prices (Germany, collected in August 2010) for bulk chemicals as given by relevant suppliers (Supplementary information, Table S1). Thus, the running cost for chemicals for the pretreatment with $\mathrm{ClO}_{2} / \mathrm{NH}_{4}{ }^{+}, \mathrm{ClO}_{2}{ }^{-} / \mathrm{NH}_{4}{ }^{+}$, and $\mathrm{MnO}_{4}{ }^{-} / \mathrm{NH}_{4}{ }^{+}$, were estimated at 2.1, 0.8 , and $3.8 \mathrm{c} € / \mathrm{m}^{3}$, respectively. This is a reasonable price compared to the total costs of drinking water production.

So far, we are aware of two treatment facilities in Netherlands (PWN Water Supply Company and DUNEA) that are treating similar type of water matrixes to DTU tap water for ECs removal (including atrazine) and have naturally high content of $\mathrm{Br}^{-1}(300-500 \mu \mathrm{g} / \mathrm{L})$. PWN decided to install a $\mathrm{UVC} / \mathrm{H}_{2} \mathrm{O}_{2}$ treatment instead of $\mathrm{O}_{3}([23]$, while DUNEA used a multiple barrier approach of combined $\mathrm{O}_{3} / \mathrm{H}_{2} \mathrm{O}_{2}$ and UVC (at low UV and $\mathrm{O}_{3}$ doses) [52]. It is our belief that the proposed new pre-treatment could allow more economical solutions for such cases in the future. Based on the treatment goals that each facility has, they may choose the $\mathrm{MnO}_{4}{ }^{-} / \mathrm{NH}_{4}{ }^{+}$pre-treatment was the most efficient for achieving a log removal of atrazine and inhibiting bromate formation below $10 \mu \mathrm{g} / \mathrm{L}$, or the less expensive $\mathrm{ClO}_{2}{ }^{-} / \mathrm{NH}_{4}{ }^{+}$, if the requirements for atrazine removal are reduced to $70 \%$.

\section{Conclusions}

To conclude, among the array of oxidants tested, $\mathrm{ClO}_{2}, \mathrm{ClO}_{2}{ }^{-}$, and $\mathrm{MnO}_{4}{ }^{-}$with $\mathrm{NH}_{4}{ }^{+}$were the most promising pre-treatments for controlling $\mathrm{BrO}_{3}{ }^{-}$formation and atrazine removal during the ozonation of ground-water. $\mathrm{By}$ varying the oxidant and $\mathrm{NH}_{4}{ }^{+}$concentrations, the optimum conditions of each of the abovementioned pretreatments were determined to be: $0.6 \mathrm{mg} / \mathrm{L} \mathrm{ClO}_{2} / 0.1 \mathrm{mg} / \mathrm{L} \mathrm{NH}_{4}{ }^{+}, 0.6 \mathrm{mg} / \mathrm{L} \mathrm{ClO}_{2}{ }^{-} / 0.4 \mathrm{mg} / \mathrm{L} \mathrm{NH}_{4}{ }^{+}$, and $2.4 \mathrm{mg} / \mathrm{L}$ $\mathrm{MnO}_{4}{ }^{-} / 0.4 \mathrm{mg} / \mathrm{L} \mathrm{NH}_{4}{ }^{+}$. These pre-treatments were found not to be affected by the addition steps (single or two stage addition). Experiments performed in the absence of $\mathrm{NH}_{4}{ }^{+}$, confirmed its importance on the mechanism that reduces $\mathrm{BrO}_{3}{ }^{-}$formation during ozonation, as well as side mechanisms that affect $\mathrm{BrO}_{3}{ }^{-}$formation and atrazine removal. Finally, the running cost for chemicals for the pretreatment with $\mathrm{ClO}_{2} / \mathrm{NH}_{4}{ }^{+}, \mathrm{ClO}_{2}{ }^{-} / \mathrm{NH}_{4}{ }^{+}$, and $\mathrm{MnO}_{4}{ }^{-}$ $/ \mathrm{NH}_{4}{ }^{+}$, were estimated at $2.1,0.8$, and $3.8 \mathrm{c} € / \mathrm{m}^{3}$, respectively which is considered reasonable for drinking water production.

\section{Acknowledgments}

This research was funded by Siemens AG Water Technologies. Special thanks for the support go to the Head of Technology, Siemens Industry, Prof. Dr.-Ing. Dieter Wegener. The authors are grateful to Professor Emeritus Dr. Hans Mosbæk for his assistance and insightful input on the $\mathrm{BrO}_{3}{ }^{-}$analysis and the technicians Christina Maj Hagberg, and Jens Schaarup Sørensen of DTU-Environment for their assistance with the $\mathrm{BrO}_{3}{ }^{-}$analysis.

\section{Supplementary information}

Supplementary data associated with this article can be found in a separate document.

\section{References:}

[1] A.A. de la Cruz, M.G. Antoniou, A. Hiskia, M. Pelaez, W. Song, K.E. O'Shea, X. He, D.D. Dionysiou, Can we effectively degrade microcystins? - implications on human health, Anti-Cancer Agents in Medicinal Chemistry. 11 (2011) 19-37.

[2] J. Hollender, S.G. Zimmermann, S. Koepke, M. Krauss, C.S. Mcardell, C. Ort, H. Singer, U. Von Gunten, H. Siegrist, Elimination of organic micropollutants in a municipal wastewater treatment plant upgraded with a 
full-scale post-ozonation followed by sand filtration, Environmental Science and Technology. 43 (2009) 78627869.

[3] G.D. Onstad, S. Strauch, J. Meriluoto, G.A. Codd, U. Von Gunten, Selective oxidation of key functional groups in cyanotoxins during drinking water ozonation, Environmental Science and Technology. 41 (2007) 43974404.

[4] M.M. Huber, S. Canonica, G.-. Park, U. Von Gunten, Oxidation of pharmaceuticals during ozonation and advanced oxidation processes, Environmental Science and Technology. 37 (2003) 1016-1024.

[5] M. Esperanza, M.T. Suidan, R. Marfil-Vega, C. Gonzalez, G.A. Sorial, P. McCauley, R. Brenner, Fate of sex hormones in two pilot-scale municipal wastewater treatment plants: Conventional treatment, Chemosphere. 66 (2007) $1535-1544$.

[6] B.L. Loeb, Ozone: Science and engineering: Thirty-three years and growing, Ozone: Science and Engineering. 33 (2011) 329-342.

[7] M.M. Huber, A. Göbel, A. Joss, N. Hermann, D. Löffler, C.S. McArdell, A. Ried, H. Siegrist, T.A. Ternes, U. Von Gunten, Oxidation of pharmaceuticals during ozonation of municipal wastewater effluents: A pilot study, Environmental Science and Technology. 39 (2005) 4290-4299.

[8] U. Von Gunten, Ozonation of drinking water: Part II. Disinfection and by-product formation in presence of bromide, iodide or chlorine, Water Res. 37 (2003) 1469-1487.

[9] S. Chiron, A. Fernandez-Alba, A. Rodriguez, E. Garcia-Calvo, Pesticide chemical oxidation: State-of-theart, Water Res. 34 (2000) 366-377.

[10] K. Lekkerkerker, J. Scheideler, S.K. Maeng, A. Ried, J.Q.J.C. Verberk, A.H. Knol, G. Amy, J.C. Van Dijk, Advanced oxidation and artificial recharge: A synergistic hybrid system for removal of organic micropollutants, Water Science and Technology: Water Supply. 9 (2009) 643-651.

[11] K.M.S. Hansen, H.R. Andersen, A. Ledin, Ozonation of estrogenic chemicals in biologically treated sewage, Water Science and Technology. 62 (2010) 649-657.

[12] M.G. Antoniou, G. Hey, S. Rodríguez Vega, A. Spiliotopoulou, J. Fick, M. Tysklind, J. la Cour Jansen, H.R. Andersen, Required ozone doses for removing pharmaceuticals from wastewater effluents, Sci. Total Environ. 456-457 (2013) 42-49.

[13] J. Tuerk, B. Sayder, A. Boergers, H. Vitz, T.K. Kiffmeyer, S. Kabasci, Efficiency, costs and benefits of AOPs for removal of pharmaceuticals from the water cycle, Water Science and Technology. 61 (2010) 985-993.

[14] H. Kusic, N. Koprivanac, A.L. Bozic, Minimization of organic pollutant content in aqueous solution by means of AOPs: UV- and ozone-based technologies, Chem. Eng. J. 123 (2006) 127-137.

[15] M.J. Watts, K.G. Linden, Chlorine photolysis and subsequent $\mathrm{OH}$ radical production during UV treatment of chlorinated water, Water Res. 41 (2007) 2871-2878.

[16] C. Sichel, C. Garcia, K. Andre, Feasibility studies: UV/chlorine advanced oxidation treatment for the removal of emerging contaminants, Water Res. 45 (2011) 6371-6380. 
[17] A. Driedger, E. Staub, U. Pinkernell, B. Mariñas, W. Köster, U.v. Gunten, Inactivation of bacillus subtilis spores and formation of bromate during ozonation, Water Res. 35 (2001) 2950-2960.

[18] U. von Gunten, The basics of oxidants in water treatment. Part B: Ozone reactions, Water Science and Technology. 55 (2007) 25-29.

[19] K.L. Rakness, Ozone in Drinking Water Treatment: Process Design, Operation and Optimization (2005) American Water Work Association, Denver, USA, pp 302.

[20] J. Staehelln, J. Hoigné, Decomposition of ozone in water: Rate of initiation by hydroxide ions and hydrogen peroxide, Environmental Science and Technology. 16 (1982) 676-681.

[21] S.G. Zimmermann, M. Wittenwiler, J. Hollender, M. Krauss, C. Ort, H. Siegrist, U. von Gunten, Kinetic assessment and modeling of an ozonation step for full-scale municipal wastewater treatment: Micropollutant oxidation, by-product formation and disinfection, Water Res. 45 (2011) 605-617.

[22] B. Legube, B. Parinet, F. Berne, J.-. Croue, Bromate surveys in French drinking waterworks, Ozone: Science and Engineering. 24 (2002) 293-304.

[23] J.C. Kruithof, P.C. Kamp, B.J. Martijn, UV/H2O2 treatment: A practical solution for organic contaminant control and primary disinfection, Ozone: Science and Engineering. 29 (2007) 273-280.

[24] Y. Kurokawa, A. Maekawa, M. Takahashi, Y. Hayashi, Toxicity and carcinogenicity of potassium bromate - A new renal carcinogen, Environ. Health Perspect. 87 (1990) 309-335.

[25] Council Directive 98/83/EC of 3 November 1998 on the quality of water intended for human consumption, Council Directive 98/83/EC of 3 November 1998 on the Quality of Water Intended for Human Consumption (1998).

[26] USEPA 2010. Unites States Environmental Protection Agency (US EPA) Revised State Implementation Guidance for the Consumer Confidence Report (CCR) Rule.

[27] S. Liang, T.I. Yun, S.W. Krasner, R.S. Yates, Evaluation of Emerging Bromate Control Strategies, American Water Works Association Annual Conference and Exposition 2012, ACE 2012 (2010) 1-10.

[28] M.D. Williams, B.M. Coffey, S.W. Krasner, Evaluation of $\mathrm{pH}$ and ammonia for controlling bromate during Cryptosporidium disinfection, J. Am. Water Works Assoc. 95 (2003) 82-93.

[29] USEPA 2006. National Primary Drinking Water Regulations: Stage 2 Disinfectants and Disinfection Byproducts Rule EPA-HQ-OW-2002-0043. Publication date $4^{\text {th }}$ January, 2006

[30] U. Pinkernell, U. Von Gunten, Bromate minimization during ozonation: Mechanistic considerations, Environmental Science and Technology. 35 (2001) 2525-2531.

[31] M. Buffle, S. Galli, U. Von Gunten, Enhanced bromate control during ozonation: The chlorine-ammonia process, Environmental Science and Technology. 38 (2004) 5187-5195.

[32] D.D. Rittmann, Impact of chlorine dioxide pre-oxidation of ozone on bromate formation, Am. Water Works Assoc. - Water Qual. Technol. Conf. Expo. : Taking Water Qual. New Heights (2006) 648-666. 
[33] F. Parrino, G. Camera-Roda, V. Loddo, V. Augugliaro, L. Palmisano, Photocatalytic ozonation: Maximization of the reaction rate and control of undesired by-products, Applied Catalysis B: Environmental. 178 (2015) 37-43.

[34] M.G. Antoniou, H.R. Andersen, Evaluation of pretreatments for inhibiting bromate formation during ozonation, Environmental Technology (United Kingdom). 33 (2012) 1747-1753.

[35] R. Song, P. Westerhoff, R. Minear, G. Amy, Bromate minimization during ozonation, Journal American Water Works Association. 89 (1997) 69-75.

[36] D. Eberle, Z. Chowdhury, L. Passantino, S. Bontrager, Mitigation of ozone-induced bromate by carbon dioxide and chlorine/ammonia processes, Environmental Engineer: Applied Research and Practice. 7 (2009) 2938.

[37] F.J. Beltrán, J.F. García-Araya, P.M. Álvarez, J. Rivas, Aqueous degradation of atrazine and some of its main by-products with ozone-hydrogen peroxide, Journal of Chemical Technology and Biotechnology. 71 (1998) 345-355.

[38] J.L. Acero, K. Stemmler, U. Von Gunten, Degradation kinetics of atrazine and its degradation products with ozone and $\mathrm{OH}$ radicals: A predictive tool for drinking water treatment, Environmental Science \& Technology 2000. 34 (2000) 591-597.

[39] WFD 2000, Directive 2000/60/EC of the European Parliament and of the Council of 23 October 2000 establishing a framework for Community action in the field of water policy http://eur-lex.europa.eu/legal-content/EN/TXT/?uri=CELEX:32000L0060 (last accessed: March $3^{\text {rd }}, 2016$ )

[40] H. Bader, J. Hoigne, Determination of ozone in water by the indigo method, Water Res. 15 (1981) 449456.

[41] E. Salhi, U. Von Gunten, Simultaneous determination of bromide, bromate and nitrite in low $\mu \mathrm{g} 1-1$ levels by ion chromatography without sample pretreatment, Water Res. 33 (1999) 3239-3244.

[42] W.R. Haag, J. Hoigné, H. Bader, Improved ammonia oxidation by ozone in the presence of bromide ion during water treatment, Water Res. 18 (1984) 1125-1128.

[43] M. Buffle, J. Schumacher, S. Meylan, M. Jekel, U. Von Gunten, Ozonation and advanced oxidation of wastewater: Effect of $\mathrm{O} 3$ dose, $\mathrm{pH}, \mathrm{DOM}$ and HO.-scavengers on ozone decomposition and HO . generation, Ozone: Science and Engineering. 28 (2006) 247-259.

[44] M.G. Antoniou, A.A. De La Cruz, D.D. Dionysiou, Intermediates and reaction pathways from the degradation of microcystin-LR with sulfate radicals, Environmental Science and Technology. 44 (2010) 72387244.

[45] M.G. Antoniou, A.A. de la Cruz, D.D. Dionysiou, Degradation of microcystin-LR using sulfate radicals generated through photolysis, thermolysis and e- transfer mechanisms, Applied Catalysis B: Environmental. 96 (2010) 290-298.

[46] H. Hoigne, H. Bader, Rate constants of reactions of ozone with organic and inorganic compounds in water. II. Dissociating organic compounds, Water Res. 17 (1983) 185-194. 
[47] L. Huang, L. Li, W. Dong, Y. Liu, H. Hou, Removal of ammonia by OH radical in aqueous phase, Environmental Science and Technology. 42 (2008) 8070-8075.

[48] S.N. Gibson, Oxidation of pharmaceuticals and personal care products by permanganate. , Georgia Institute of Technology, Atlanta, (2010) 1-92.

[49] B.W. Lykins Jr., W. Koffskey, Products identified at an alternative disinfection pilot plant, Environ. Health Perspect. Vol. 69 (1986) 119-128.

[50] W. Dong, Z. Dong, F. Ouyang, Y. Dong, Potassium permanganate/ozone combined oxidation for minimizing bromate in drinking water, Advanced Materials Research. 113-116 (2010) 1490-1495.

[51] Z. Liu, Y. Cui, J. Chen, Z. Yan, The control of bromate formation in ozonation of bromide-containing water, Desalin. Water Treat. 52 (2014) 4942-4946.

[52] K. Lekkerkerker-Teunissen, A.H. Knol, L.P. Van Altena, C.J. Houtman, J.Q.J.C. Verberk, J.C. Van Dijk, Serial ozone/peroxide/low pressure UV treatment for synergistic and effective organic micropollutant conversion, Separation and Purification Technology. 100 (2012) 22-29.

[53] U. Von Gunten, J. Hoigne, Bromate formation during ozonation of bromide-containing waters: Interaction of ozone and hydroxyl radical reactions, Environmental Science and Technology. 28 (1994) 12341242 . 


\title{
Novel pre-treatments to control bromate formation during ozonation
}

\author{
Maria G. Antoniou ${ }^{1,2^{*}}$, Cosima Sichel ${ }^{3,4}$, Klaus Andre ${ }^{3}$ and Henrik R. Andersen ${ }^{1}$. \\ ${ }^{1}$ Technical University of Denmark (DTU), Department of Environmental Engineering, Miljoevej, \\ Building 113, 2800 Kgs. Lyngby \\ ${ }^{2}$ Cyprus University of Technology Department of Environmental Science and Technology, Corner \\ of Athinon and Anexartisias 57, PO Box: 50329, 3603 Lemesos, Cyprus \\ ${ }^{3}$ Siemens AG, Industry Sector, Industry Automation Division, Water Technologies, Auf der Weide \\ 10, 89312 Günzburg, Germany \\ ${ }^{4}$ Siemens AG, Industry Sector, Industry Automation Division, Sensors and Communication, I IA \\ SC S PI IBD-E, Oestliche Rheinbrueckenstr. 50, 76187 Karlsruhe, Germany
}

*Corresponding authors e-mail: maria.antoniou@cut.ac.cy. 


\section{Supplementary Figures and Schemes Captions}

Figure S1: Reproducibility of the experiments on $\mathrm{BrO}_{3}{ }^{-}$formation and ATR removal at the highest doses. Experimental conditions: $\mathrm{O}_{3}=3.5 \mathrm{mg} / \mathrm{L} ; \mathrm{Br}^{-}=100 \mu \mathrm{g} / \mathrm{L} ; \mathrm{ATR}_{\mathrm{o}}=200 \mu \mathrm{g} / \mathrm{L} ; \mathrm{NH}_{4}^{+}=4$, $\mathrm{mg} / \mathrm{L} ;\left[\mathrm{NH}_{4}^{+}\right] /\left[\mathrm{Br}^{-}\right]=178 ;[\mathrm{Ox}]=60 \mu \mathrm{M} ;[\mathrm{Ox}] /\left[\mathrm{Br}^{-}\right]=48$.

Table S1: Cost of pre-treatments based on the optimum oxidants $\left(\mathrm{Cl}_{2}, \mathrm{ClO}_{2}, \mathrm{ClO}_{2}{ }^{-}\right.$, and $\left.\mathrm{MnO}_{4}^{-}\right)$ and $\mathrm{NH}_{4}{ }^{+}$concentrations 
Materials and Methods:

Chlorine Dioxide: For the preparation of $1 \mathrm{~L}$ of $\mathrm{ClO}_{2}, 400 \mathrm{~mL}$ of Milli-Q water were mixed with $25 \mathrm{~mL}$ of $\mathrm{HCl}(9 \%)$ and $25 \mathrm{~mL}$ of $\mathrm{NaClO} 2(7.5 \%=75 \mathrm{~g} / \mathrm{L})$. The glass bottle was covered with aluminum foil and the cap was placed carefully on the top allowing space for gas release. The next day milli-Q water was added to complete the volume at $1000 \mathrm{~mL}$. The concentration of the stock was measured photometrically with a HACH LANGE DR2800. 


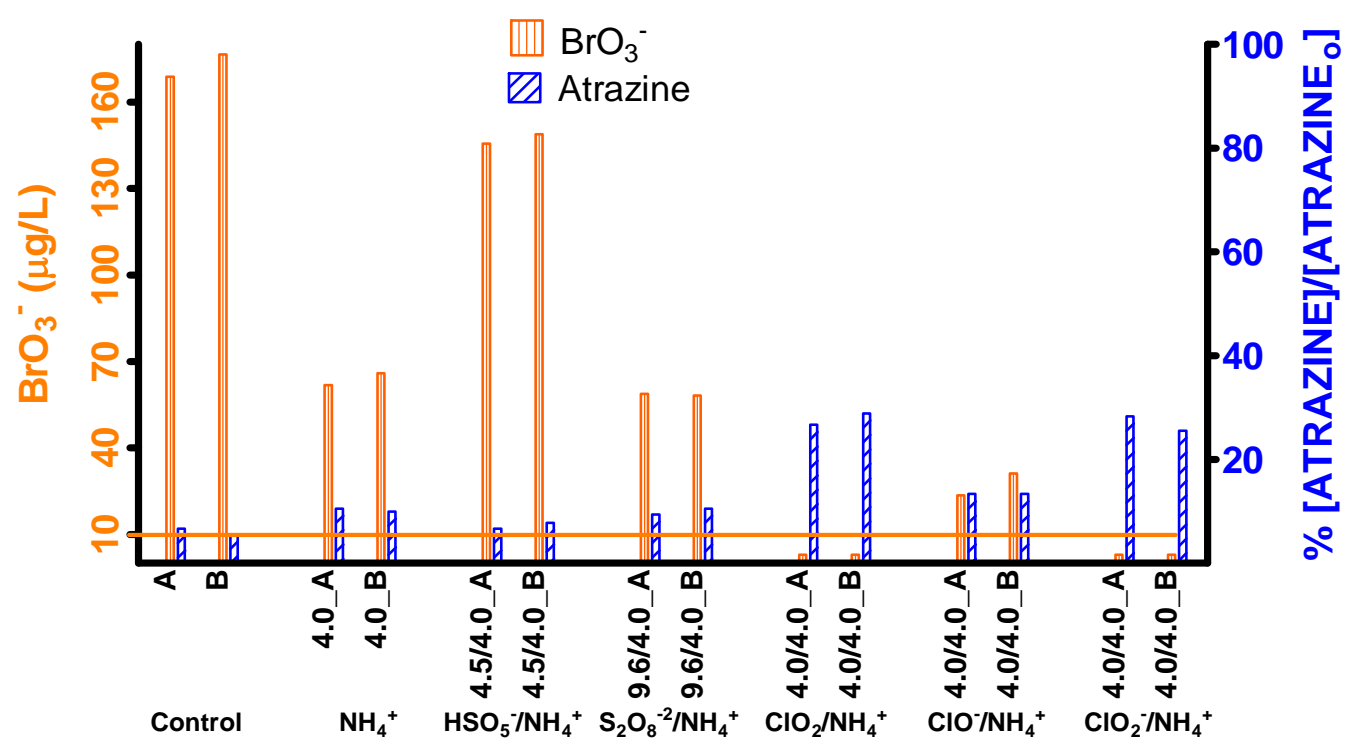

Figure S1: Reproducibility of the experiments on $\mathrm{BrO}_{3}{ }^{-}$formation and $\mathrm{ATR}$ removal at the highest doses. Experimental conditions: $\mathrm{O}_{3}=3.5 \mathrm{mg} / \mathrm{L} ; \mathrm{Br}^{-}=100 \mu \mathrm{g} / \mathrm{L} ; \mathrm{ATR}_{\mathrm{o}}=200 \mu \mathrm{g} / \mathrm{L} ; \mathrm{NH}_{4}^{+}=4$, $\mathrm{mg} / \mathrm{L} ;\left[\mathrm{NH}_{4}^{+}\right] /\left[\mathrm{Br}^{-}\right]=178 ;[\mathrm{Ox}]=60 \mu \mathrm{M} ;[\mathrm{Ox}] /\left[\mathrm{Br}^{-}\right]=48$.

After obtaining the data depicted in Figure 1 it was decided to verify the reproducibility of the experiments. Therefore, the experiments with the highest level of oxidant concentration $\left(\left[\mathrm{NH}_{4}^{+}\right] /\left[\mathrm{Br}^{-}\right]=189,[\right.$ Oxidant $]=60 \mu \mathrm{M}$ and $\left.\mathrm{O}_{3}=3.5 \mathrm{mg} / \mathrm{L}\right)$, were repeated in two separate batches (A and $\mathrm{B}$ ) (Figure $\mathrm{S} 1$ ). It is evident from Figure $\mathrm{S} 1$, that both $\mathrm{BrO}_{3}{ }^{-}$and atrazine concentrations are very close and in some cases the error between the measurements was lower than the error of the analytical method. The data were also statistically analyzed by performing t-testing at $95 \%$ confidence, which confirmed that the data do not vary statistically. This means that the way the experiments were conducted is generating reliable and reproducible results. 
Table S1: DTU-tap water analysis

\section{Expanded water control}

With organic micro pollutants

Analysis Report Lyngby Waterworks April 29, 2008

\begin{tabular}{|c|c|c|c|c|c|c|}
\hline Parameter & & & Result & $\begin{array}{l}\text { Water Quality } \\
\text { Requirements 1) }\end{array}$ & Method & St \\
\hline Platinum & $\mathrm{Pt}$ & $\mathrm{mg} / \mathrm{l}$ & 4 & 5 & DS/EN7887 & $5 \%$ \\
\hline Turbidity & & FTU & 0,15 & 0,3 & DS/EN27027 & $5 \%$ \\
\hline $\mathrm{pH}$ & & $\mathrm{pH}$ & 7,65 & $7,0-8,5$ & DS287 & \\
\hline Conductivity & & $\mathrm{mS} / \mathrm{m}$ & 82 & & DS/EN27888 & $2 \%$ \\
\hline Evaporation residue & & $\mathrm{mg} / \mathrm{l}$ & 485 & 1500 & DS204 & $5 \%$ \\
\hline NVOC & $\mathrm{C}$ & $\mathrm{mg} / 1$ & 1,8 & 4 & SM5310 & $5 \%$ \\
\hline Calcium & $\mathrm{Ca}^{2+}$ & $\mathrm{mg} / 1$ & 111 & & DS/EN14911 & $3 \%$ \\
\hline Magnesium & $\mathrm{Mg}^{2+}$ & $\mathrm{mg} / 1$ & 17 & 50 & DS/EN14911 & $3,50 \%$ \\
\hline Total Hardness & & ${ }^{\circ} \mathrm{dH}$ & 19,4 & & DS/EN14911 & $3,50 \%$ \\
\hline Sodium & $\mathrm{Na}^{+}$ & $\mathrm{mg} / 1$ & 32 & 175 & DS/EN14911 & $3 \%$ \\
\hline Potassium & $\mathrm{K}^{+}$ & $\mathrm{mg} / 1$ & 4,2 & 10 & DS/EN14911 & $3 \%$ \\
\hline Ammonium & $\mathrm{NH}_{4}^{+}$ & $\mathrm{mg} / \mathrm{l}$ & 0,05 & 0,05 & SM 418B & $4 \%$ \\
\hline Iron & $\mathrm{Fe}$ & $\mathrm{mg} / 1$ & 0,02 & 0,1 & DS225 & $4 \%$ \\
\hline Manganese & $\mathrm{Mn}$ & $\mathrm{mg} / \mathrm{l}$ & 0,005 & 0,02 & DS227 & $5 \%$ \\
\hline Bicarbonate & $\mathrm{HCO}_{3}^{-}$ & $\mathrm{mg} / \mathrm{l}$ & 332 & & DS/EN9963-1 & $2 \%$ \\
\hline Chloride & $\mathrm{Cl}^{-}$ & $\mathrm{mg} / \mathrm{l}$ & 71 & 250 & DS/EN10304 & $1,50 \%$ \\
\hline Sulphate & $\mathrm{SO}_{4}{ }^{2-}$ & $\mathrm{mg} / 1$ & 46 & 250 & DS/EN10304 & $1,50 \%$ \\
\hline Nitrate & $\mathrm{NO}_{3}^{-}$ & $\mathrm{mg} / \mathrm{l}$ & 2,6 & 50 & DS/EN10304 & $2,50 \%$ \\
\hline Nitrite & $\mathrm{NO}_{2}^{-}$ & $\mathrm{mg} / \mathrm{l}$ & 0,01 & 0,01 & DS6777 & $1,50 \%$ \\
\hline Phosphorus, total & $\mathrm{P}$ & $\mathrm{mg} / \mathrm{l}$ & 0,02 & 0,15 & DS292 & $5 \%$ \\
\hline Fluoride & $\mathrm{F}^{-}$ & $\mathrm{mg} / 1$ & 0,35 & 1,5 & DS/EN10304 & $3 \%$ \\
\hline Oxygen & $\mathrm{O}_{2}$ & $\mathrm{mg} / \mathrm{l}$ & 8,5 & & DS2205 & $5 \%$ \\
\hline AGGR. Carbon dioxide & $\mathrm{CO}_{2}$ & $\mathrm{mg} / 1$ & 2 & 2 & DS236 & $2 \%$ \\
\hline
\end{tabular}

1) See Statutory Order no. 871 dated 21 September 2001

* Outside of accreditation

! Water quality requirements not met

m.l.: measurable limit 
Udvidet drikkevandskontrol

Med organiske mikroforureninger

Analyserapport Lyngby Vandværk 29. april 2008

\begin{tabular}{|l|l|r|r|r|r|r|}
\hline \multicolumn{7}{|c|}{ Analyserapport Lyngby Vandvark 29. april 2008 } \\
Fysisk-kemisk undersogelse
\end{tabular}

1) Se Miljoministeriets bekendtgorelse $\mathrm{nr}, 871$ af 21. september 2001

* Uden for akkreditering

! Vandkvalitetskrav ikke overholdt

i.m.: Ikke målelig

St: Total fejl 
Table S2: Cost ${ }^{*}$ of pre-treatments based on the optimum oxidants $\left(\mathrm{Cl}_{2}, \mathrm{ClO}_{2}, \mathrm{ClO}_{2}^{-}\right.$, and $\left.\mathrm{MnO}_{4}^{-}\right)$and $\mathrm{NH}_{4}^{+}$concentrations

\begin{tabular}{|c|c|c|c|c|c|c|c|}
\hline Treatment & $\begin{array}{c}\mathrm{O}_{3} \text { dose } \\
\mathrm{g} / \mathrm{m}^{3}\end{array}$ & Oxidant & $\begin{array}{c}\text { Oxidant dose } \\
\text { g/m }\end{array}$ & $\begin{array}{l}\mathrm{NH}_{4}{ }^{+} \\
\text {dose } \\
\mathrm{g} / \mathrm{m}^{3}\end{array}$ & $\begin{array}{c}\begin{array}{c}\text { Cost of } \\
\text { oxidant }\end{array} \\
€ / \mathrm{m}^{3}\end{array}$ & $\begin{array}{c}\text { Cost of } \mathrm{NH}_{4}^{+} \\
€ / \mathrm{m}^{3}\end{array}$ & $\begin{array}{c}\text { Pre-Treatment Cost } \\
\qquad € € / \mathbf{m}^{3}\end{array}$ \\
\hline Pretreatment with $\mathrm{NH}_{4}^{+}$ & & & & 1 & N/A & 0,0022 & 0.22 \\
\hline Pretreatment with $\mathrm{NH}_{4}{ }^{+}-\mathrm{Cl}_{2}$ & & $\mathrm{Cl}_{2}$ & 4 & 4 & 0,008 & 0.0089 & 1,69 \\
\hline Pretreatment with $\mathrm{NH}_{4}^{+}-\mathrm{MnO}_{4}^{-}$ & 3.5 & $\mathrm{MnO}_{4}^{-}$ & 2.4 & 0,4 & 0,038 & 0.0009 & 3.84 \\
\hline Pretreatment with $\mathrm{NH}_{4}^{+}-\mathrm{ClO}_{2}^{-}$ & 3.5 & $\mathrm{ClO}_{2}^{-}$ & 0.6 & 0,4 & 0,007 & 0.0009 & 0.76 \\
\hline Pretreatment with $\mathrm{NH}_{4}^{+}-\mathrm{ClO}_{2}$ & 3.5 & $\mathrm{ClO}_{2}$ & 0.6 & 0,1 & 0,021 & 0.0002 & 2.12 \\
\hline
\end{tabular}

*Based on German market prices for bulk chemicals as given by relevant suppliers obtained August 2010. 